\title{
Multi-sensor analysis of convective activity in central Italy during the HyMeX SOP 1.1
}

\author{
N. Roberto ${ }^{1}$, E. Adirosi ${ }^{1}$, L. Baldini ${ }^{1}$, D. Casella ${ }^{1}$, S. Dietrich ${ }^{1}$, P. Gatlin ${ }^{2}$, G. Panegrossi ${ }^{1}$, M. Petracca ${ }^{1,3}$, P. Sanò ${ }^{1}$, \\ and A. Tokay ${ }^{4,5}$ \\ ${ }^{1}$ CNR - Istituto di Scienze dell' Atmosfera e del Clima, Rome, Italy \\ ${ }^{2}$ NASA Marshall Space Flight Center, Huntsville, AL, USA \\ ${ }^{3}$ Department of Physics, University of Ferrara, Ferrara, Italy \\ ${ }^{4}$ Joint Center for Earth Systems Technology, University of Maryland Baltimore County, Baltimore, MD, USA \\ ${ }^{5}$ NASA Goddard Space Flight Center, Greenbelt, MD, USA \\ Correspondence to: N. Roberto (nicoletta.roberto@artov.isac.cnr.it)
}

Received: 30 July 2015 - Published in Atmos. Meas. Tech. Discuss.: 7 September 2015

Revised: 12 January 2016 - Accepted: 14 January 2016 - Published: 17 February 2016

\begin{abstract}
A multi-sensor analysis of convective precipitation events that occurred in central Italy in autumn 2012 during the HyMeX (Hydrological cycle in the Mediterranean experiment) Special Observation Period (SOP) 1.1 is presented. Various microphysical properties of liquid and solid hydrometeors are examined to assess their relationship with lightning activity. The instrumentation used consisted of a C-band dual-polarization weather radar, a 2-D video disdrometer, and the LINET lightning network. Results of $\mathbf{T}$ matrix simulation for graupel were used to (i) tune a fuzzy logic hydrometeor classification algorithm based on Liu and Chandrasekar (2000) for the detection of graupel from Cband dual-polarization radar measurements and (ii) to retrieve graupel ice water content. Graupel mass from radar measurements was related to lightning activity. Three significant case studies were analyzed and linear relations between the total mass of graupel and number of LINET strokes were found with different slopes depending on the nature of the convective event (such as updraft strength and freezing level height) and the radar observational geometry. A high coefficient of determination $\left(R^{2}=0.856\right)$ and a slope in agreement with satellite measurements and model results for one of the case studies (15 October 2012) were found. Results confirm that one of the key features in the electrical charging of convective clouds is the ice content, although it is not the only one. Parameters of the gamma raindrop size distribution measured by a 2-D video disdrometer revealed the transition from a convective to a stratiform regime. The raindrop size
\end{abstract}

spectra measured by a 2-D video disdrometer were used to partition rain into stratiform and convective classes. These results are further analyzed in relation to radar measurements and to the number of strokes. Lightning activity was not always recorded when the precipitation regime was classified as convective rain. High statistical scores were found for relationships relating lightning activity to graupel aloft.

\section{Introduction}

Cloud microphysical processes and their relation to the electrical activity during intense convective precipitation events is an issue of strong interest, especially for its impact on numerical weather prediction (NWP) models. The contribution of very fine-scale kinematic and microphysical processes and their nonlinear interactions with larger scale processes limit the ability of current NWP models to predict these phenomena (e.g., Weisman et al., 2008; Miglietta and Rotunno, 2012). Many projects and fields campaigns aimed at investigating convection by deploying ground and airborne instruments have been conducted especially in the USA and in tropical regions, the most recent one being the multi-year and multi-site Chuva in Brazil (Machado et al., 2013), or the Midlatitude Continental Convective Clouds Experiment (MC3E) in Oklahoma (Petersen and Jensen, 2012). Although similar experiments are not so frequent in the Mediterranean, the ongoing Hydrological cycle in the Mediterranean ex- 
periment (HyMeX) includes some experimental activities to investigate convection. In particular, the Special Observation Period (SOP) 1.1 that took place between 5 September and 6 November 2012 in target regions of the Mediterranean region was dedicated to observing heavy precipitation and flash floods (Ducrocq et al., 2014). Several instrumented hydrometeorological sites, three of them in Italy Liguria-Tuscany (LT), northeastern Italy (NEI), and central Italy $(\mathrm{CI})$ - were set up to investigate the mechanisms responsible for the heavy precipitation events in these areas (see Ferretti et al., 2014; for an overview of the SOP activities in Italy). The CI site is of particular interest both for its central position between the Adriatic Sea and the Tyrrhenian Sea, and because it includes the densely populated urban area of Rome consisting of approximately 4 million inhabitants. In the late summer-early autumn, severe weather conditions are quite frequent in $\mathrm{CI}$ and are mostly related to the development of intense convective systems (Melani et al., 2013). The correct forecast of precipitation associated with these events is linked to the ability of numerical models to initiate convection, which is especially challenging over the Tyrrhenian Sea, and with the correct representation of cloud microphysical processes (Ferretti et al., 2014). The microphysical schemes used by NWP models often misrepresent the auto-conversion processes as well as the characteristics of cloud particles (e.g., size distribution, densities). The microphysical parameterization should be tuned to the different types of precipitation regimes (i.e., convective vs. stratiform) throughout the life cycle of the simulated event (Lang et al., 2003; Wu et al., 2013). Ground-based instruments such as weather radars and disdrometers can be used to gain insights about the microphysical structure of a precipitating cloud and to derive the parameters required by microphysics schemes.

Lightning information is useful to monitor the evolution of convective events (e.g., Gatlin and Goodman, 2010) as well as to assess the NWP model ability to reproduce their intensity and predict their evolution in time (e.g., Federico et al., 2014). Robust relationships of lightning activity to cloud microphysics and dynamical properties (such as updraft strength) could be exploited by assimilating lightning data into NWP models to improve the initiation and forecast in both time and space of convective activity (Lynn et al., 2012; Lagouvardos et al., 2013).

Numerous studies have investigated the relationship between lightning and heavy precipitation, and, more specifically, between the volume of precipitable water and lightning flashes (or lightning strokes), and it was found to depend on climatology as well as on geographical location (e.g., Petersen and Rutledge, 1998 and references therein; Lang and Rutledge, 2002; Latham et al., 2004; Albrecht et al., 2011). However, the relationship between total lightning activity and ice mass appears to be more robust (Petersen et al., 2005; hereinafter PE05, Deierling et al., 2008; Formenton et al., 2013, hereinafter FO13). The non-inductive cloud charging mechanism, considered to be the main source of charges involved in lightning flashes within thunderstorms (Saunders, 1993; Latham et al., 2007), is mainly related to the collisions between ice crystals (positively charged) and graupel (typically associated with negative charge in the cloud), suggesting a relation between ice mass and lightning activity. Several studies over the last decade have shown that dual-polarization (DP) radar measurements may exhibit signatures that can be tied to lightning activity (e.g., López and Aubagnac, 1997; Goodman et al., 1989; Carey and Rutledge, 1996, 2000; Wiens et al., 2005; Preston and Fuelberg, 2015). López and Aubagnac (1997) showed that the evolution of lightning activity in an Oklahoma supercell thunderstorm that produced copious amounts of hail was related to the changes in the microphysical characteristics of the storm that were inferred from polarimetric radar measurements. Their results indicate that the development of graupel above the freezing level is related to the overall increase/decrease in the number of cloud-to-ground (CG) flashes. Carey and Rutledge (2000) showed that CG lightning flashes were highly correlated with radar-inferred mixed-phase ice mass in time and space. Moiser et al. (2011) used the radar-derived vertically integrated ice (VII) to forecast CG lightning and showed that any increase of VII over $0.42 \mathrm{~kg} \mathrm{~m}^{-2}$ is a sufficient amount of precipitation mass for cloud electrification. Contributions concerning quantitative relationships between graupel mass and lightning activity also come from studies based on satellite observations or numerical cloud electrification models. PE05 used cloud ice microphysical information obtained from the Precipitation Radar onboard the National Aeronautics and Space Administration (NASA) Tropical Rainfall Measuring Mission (TRMM) satellite to find global relationships between ice water content and the lightning activity observed by the Lightning Imaging Sensor onboard TRMM. They found a linear relationship on a global scale between columnar precipitation ice mass and lightning flash density regardless of land, ocean, and coastal regimes. FO13, using a 1-D numerical cloud electrification model, found a linear relation between flash rate and a minimum threshold of columnar ice water content of graupel.

Rain at the ground, characterized by its raindrop size distribution (RSD) (i.e., the number concentration of rain drops as a function of their equivolume diameter), is measured by raindrop sampling instruments (disdrometers). RSD can present distinctive properties, allowing rain to be classified as convective or stratiform (e.g., Bringi et al., 2003; Friedrich et al., 2013) and, can be related to lightning activity. The main novelty of this work concerns the study of relationships occurring between lightning activity and different measurements characterizing different phases of precipitation (solid and liquid) and as seen using different instruments. In particular, the hypothesis of correlation between graupel mass and flashes is verified.

In this study a subset of the ground-based instruments deployed in the CI hydrometeorological site during the SOP 1.1 is used to examine the relationship between the cloud micro- 
physical parameters and the cloud electrical activity. The investigation is based on a ground-based lightning sensor network, a scanning C-band DP radar, which was installed in the southeastern part of Rome, and a nearby instrumented site ( $14 \mathrm{~km}$ from the C-band radar, in the historic center of Rome) that included a disdrometer. In such a configuration, DP radar is used to estimate the mass of graupel, while RSDs are estimated from disdrometer observations. Both estimates are analyzed in relation to the number of total lightning strokes detected by the ground-based lightning detection network or to variables inferred from such lightning measurements.

Section 2 presents the instrumentation used and some issues related to data quality. In Sect. 3, the techniques employed to retrieve graupel properties and RSD, as well as lightning data processing, are described. The data set and details of selected case studies are given in Sect. 4, while Sect. 5 discusses the important results of the study. Our conclusions can be found in the last section.

\section{Instrumentation}

Several instruments were made available during the HyMeX SOP1.1 to be deployed in the CI hydrometeorological site thanks to the cooperation amongst the Italian meteorological services and the scientific community, as well as to the contribution from NASA Global Precipitation Measurement (GPM) Ground Validation Program (Ferretti et al., 2014). Instruments selected for this study are the DP C-band radar (Polar 55C) of the National Research Council of Italy, Institute of Atmospheric Science and Climate (CNR-ISAC), and a 2-D video disdrometer (2-DVD), located in the historic center of Rome. Lightning data from the European LIghtning detection NETwork (LINET; Betz et al., 2009) made available in real time at CNR-ISAC were also used.

LINET provides continuous data for both research and operational purposes, with total lightning capability (cloud-toground (CG) and intra-cloud (IC) strokes are registered), and low-amplitude reporting capability (signals with currents below $5 \mathrm{kA}$ are recorded) utilizing very low frequency/low frequency (VLF/LF) techniques (i.e., 10 frequency intervals between 1 and $200 \mathrm{KHz}$ ). More than 120 sensors in over $20 \mathrm{Eu}$ ropean countries compose the network, with good coverage of the central and western Mediterranean region, from $10^{\circ} \mathrm{W}$ to $35^{\circ} \mathrm{E}$ in longitude and from 30 to $65^{\circ} \mathrm{N}$ in latitude. Further details and specifications are in Betz et al. (2009). The detection efficiency of ICs and CGs depends on the distance between the stroke event and the LINET sensors, and on the network baseline. In the coastal areas and over the Mediterranean basin, the baseline is larger, and weak strokes (IC or CG) may not be detected or properly located (Zinner et al., 2013).

A 2-DVD (compact version) by Joanneum Research mbH, Graz, Austria (Schönhuber et al., 2008), was installed on the roof of the Department of Electrical Engineering and Telecommunications at Sapienza University of Rome (here- inafter "Sapienza site", $41.89^{\circ} \mathrm{N}, 12.49^{\circ} \mathrm{E} ; 70 \mathrm{~m}$ a.s.l.). The 2-DVD is an optical disdrometer that provides properties of raindrops such as diameter, fall velocity, and oblateness of each particle falling through a $10 \times 10 \mathrm{~cm}^{2}$ effective measurement area (Schönhuber et al., 2008). Drop size and drop velocity measured by the 2 -DVD are more accurate across a broad spectrum of drop sizes than similar measurements collected by disdrometers employing other measuring principles (Tokay et al., 2013).

Polar $55 \mathrm{C}$ is a research-grade C-band $(5.6 \mathrm{GHz}) \mathrm{DP}$ Doppler radar located on the outskirts of Rome $\left(41.84^{\circ} \mathrm{N}\right.$, $12.65^{\circ} \mathrm{E} ; 130 \mathrm{~m}$ a.s.l.) $14 \mathrm{~km}$ southeast of the Sapienza site (Sebastianelli et al., 2013). Radar measurements were collected using a pulse duration of $0.5 \mu$ s (corresponding to a range resolution of $75 \mathrm{~m}$ ) and a pulse repetition frequency of $1200 \mathrm{~Hz}$. The scanning strategy was configured as follows: (i) a volume scan consisting of unevenly spaced elevation angles to obtain a vertical resolution of $1 \mathrm{~km}$ above the Sapienza site and eight plan position indicator (PPI) maps (elevation angles in degrees are $0.6,1.6,2.6,4.4,6.2,8.3,11.0,14.6$ ), (ii) scans at vertical incidence, and (iii) RHIs directed toward the Sapienza site. Tasks (ii) and (iii) were added to the volume scan depending on the presence of precipitation above the Polar 55C and the Sapienza site, respectively. The scanning strategy was designed to provide an update every $5 \mathrm{~min}$. During the SOP 1.1, the Polar 55C also performed operatorsupervised RHI scans along the route of a research aircraft (the Falcon 20 of Service des avions français instrumentés pour la recherche en environnement) that did not fly over CI during convection. The use of DP radar observations collected using an ad hoc scanning strategy allows quantitative graupel mass estimation to be improved, first by detecting the radar sample volume with graupel, and then by estimating the ice water content using specific algorithms. This ability of DP radar and its application to operational forecasting of the precursor microphysical conditions leading to lightning production (short-term flash forecasting), are highlighted by Woodard et al. (2012).

\section{Analysis techniques}

\subsection{Graupel detection and graupel mass estimation from DP radar measurements}

Dual-polarization radar backscattering and propagation measurements are sensitive to precipitation properties and vary with the size, shape, concentration, habit, and fall velocity of liquid and ice hydrometeors. For this reason, DP radar is capable of identifying the type of hydrometeors. Several observational studies have employed DP radar to relate microphysical properties of convective clouds to the electrical activity (López and Aubagnac, 1997; Wiens et al., 2005; Woodard et al., 2012). While most of them used radar measurements to detect ice mass by tracking one or more convective cells during their life cycle, Polar 55C radar measurements were 
Table 1. Inputs to T-matrix simulations for graupel. Spheroid and conical graupels differ mainly for the axis ratio $(b / a)$ and standard deviation of canting angle $(\sigma)$.

\begin{tabular}{lll}
\hline & Spheroid graupel & Conical graupel \\
\hline Frequency & $5.6 \mathrm{GHz}$ & $5.6 \mathrm{GHz}$ \\
Composition & Mixture of air, ice, and water & Mixture of air, ice, and water \\
Fraction of water & Uniformly distributed in $[5,55 \%]$ & Uniformly distributed in $[5 \%, 55 \%]$ \\
Density & Uniformly distributed in $[0.2,0.9] \mathrm{g} \mathrm{cm}^{-3}$ & Uniformly distributed in $[0.2,0.9] \mathrm{g} \mathrm{cm}^{-3}$ \\
Temperature & Uniformly distributed in $\left[-15,0{ }^{\circ} \mathrm{C}\right.$ & Uniformly distributed in $\left[-15,0{ }^{\circ} \mathrm{C}\right.$ \\
PSD parameters & Exponential: $D_{0}[1,3] \log N_{0}[2,3]$ & Exponential: $D_{0}[1,3] \log N_{0}[2,3]$ \\
$b / a$ & Uniformly distributed in $[0.90,1.00]^{\circ}$ & Uniformly distributed in $[0.75,1.10]^{\circ}$ \\
$\sigma$ & Uniformly distributed in $[0,15]^{\circ}$ & Uniformly distributed in $[0,30]^{\circ}$ \\
Elevation angle & $0^{\circ}$ & $0^{\circ}$ \\
\hline
\end{tabular}

employed in this study to quantify the mass of graupel embedded in the convective cells occurring within $120 \mathrm{~km}$ of the radar. First, a Hydrometeor Classification Algorithm (HCA) based on DP radar measurements is employed to identify radar volumes containing graupel. Then, ice water content of graupel for these volumes is estimated from reflectivity factor measurements, utilizing a power law relation. A specific study to optimize the HCA and the graupel mass estimation algorithm was conducted.

\subsubsection{HCA optimization for graupel identification}

A T-matrix method (Barber and Yeh, 1975) was used to study the electromagnetic scattering properties of graupel with two main purposes: (1) to define proper membership functions to identify graupel by means of a fuzzy logic HCA using C-band radar measurements, and (2) to obtain a simple algorithm to retrieve the ice water content of graupel from measured radar reflectivity factor. A broad population of graupel particle size distributions (PSDs) was obtained by randomly varying parameters of an exponential PSD (Chandrasekar et al., 2003; Dolan and Rutledge, 2009) in the form

$N(D)=N_{0} \exp \left[-3.67\left(D / D_{0}\right)\right]$

where $N_{0}\left(\mathrm{~mm}^{-1} \mathrm{~m}^{-3}\right)$ is the intercept parameter of the size distribution, $D$ is the equivalent volume particle diameter (in $\mathrm{mm}$ ), and $D_{0}$ is the median volume diameter (in $\mathrm{mm}$ ). Tmatrix simulations were performed for temperatures between -15 and $0^{\circ} \mathrm{C}$, liquid water fractions between 5 and $55 \%$, and particle densities between 0.2 and $0.9 \mathrm{~g} \mathrm{~cm}^{-3}$ (Pruppacher and Klett, 1978; Dolan and Rutledge, 2009; Dolan et al., 2013). The microphysical parameters used for simulations are summarized in Table 1. All these quantities were randomly varied, assuming a uniform distribution in the intervals defined in the table to include the heterogeneous characteristics of the different types of graupel. The wide ranges from which microphysical parameters are randomly chosen take into account mechanisms that involved graupel formation and accretion during cloud development and are consistent with graupel microphysics described in literature cited above. Some classification algorithms do not distinguish graupel from small and dense ice hydrometeors, such as small hail (Straka et al., 2000), while others categorize it as either low-density or high-density graupel (Dolan et al., 2013). A wide, single set of graupel microphysics to take into account the different types of graupel including low-density graupel to small hail was used. Graupel can take on different shapes, primarily hexagonal, lump, spheroidal, and conical, which are difficult to identify using polarimetric radar, although some studies showed that the presence of conical shapes can be inferred from differential reflectivity (Evaristo et al., 2013). Therefore, two different simulations were performed to model graupel as having either spheroidal or conical shape by varying the axis ratio (ratio of semi-minor to semi-major axis) and canting angle. The mathematical formulation described by Wang (1982) was used for modeling conically shaped graupel. The fall behavior of graupel, especially its orientation, is not well established, and some investigators have hypothesized that the larger rimed ice particles probably tumble, though conical graupel may have a preferential fall orientation (Pruppacher and Klett, 1978), oscillating between $\pm 20^{\circ}$ about its vertical axis (Zikmunda and Vali, 1972). Some graupel particles can fall with an axis ratio exceeding 1 (prolate) and other particles with an axis ratio less than 1 (oblate) (Wang, 1982). For conical shapes, we assumed a random uniform distribution between 0.75 and 1.1 for the axis ratio (Heymsfield, 1978), and a zero-mean Gaussian distribution for canting angle, with randomly varying standard deviation between 0 and $30^{\circ}$. For spheroidal shapes, the canting angle standard deviation varied between 0 and $15^{\circ}$, and the axis ratio between 0.9 and 1 (Prupaccher and Klett, 1978; Aydin and Seliga, 1984; Straka et al., 2000; Bringi et al., 1986). Figure 1 shows the output of simulated DP radar observables (obtained from 1000 iterations) for spheroidal $(a, c)$, and conical (b, d) shaped graupel. Observing the four scatter plots, $Z_{h}$ ranges from about 10 to $60 \mathrm{dBZ}$ for both shapes, while $Z_{\mathrm{dr}}$ is between 0 and $1 \mathrm{~dB}$ for spheroidal shapes, and covers a $1.5 \mathrm{~dB}$ wider range for conical shapes, including slightly negative values, with a maximum value near $2 \mathrm{~dB}$ (Fig. $1 \mathrm{a}$ and b). The simulated $K_{\mathrm{dp}}$ 

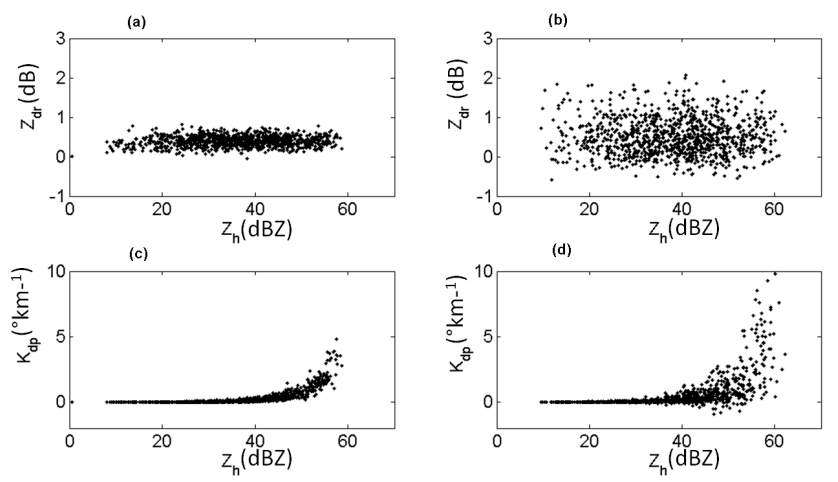

Figure 1. Scatter plots of C-band differential reflectivity $(\mathbf{a}, \mathbf{b})$ and specific differential phase shift $(\mathbf{c}, \mathbf{d})$ vs. reflectivity factor obtained by $\mathbf{T}$-matrix simulations for graupel. Left panels refer to spheroid graupel simulations (details in second column of Table 1), while right panels refer to conical graupel simulations (third column of Table 1).

values also exhibited larger variation for the conical shapes (Fig. 1c and d).

The results of $\mathbf{T}$-matrix simulations were used to define proper beta membership functions of a fuzzy logic (FL) HCA (Liu and Chandrasekar, 2000; Lim et al., 2005) tailored for $\mathrm{C}$-band and graupel detection. Inputs of the FL classificator are the Polar 55C radar measurements of $Z_{h}, Z_{\mathrm{dr}}$, and $K_{\mathrm{dp}}$, the standard deviation of the differential propagation phase shift $\left(\phi_{\mathrm{dp}}\right)$ (calculated in a $375 \mathrm{~m}$ range moving window, i.e., five $75 \mathrm{~m}$ range bins), and the height of the top of the melting layer (ML). The height of the top of ML is considered to be the $0^{\circ} \mathrm{C}$ level from vertical temperature soundings collected at the nearby ( $20 \mathrm{~km}$ south of Rome) Pratica di Mare airport (whose ICAO code is LIRE and where radio soundings are routinely collected at 00:00 and 12:00 UTC). Measurements of $Z_{h}$ and $Z_{\mathrm{dr}}$ were corrected for attenuation by utilizing linear relations between specific attenuation at horizontal polarization, specific differential attenuation, and $K_{\mathrm{dp}}$ (parameterizations used can be found in Baldini et al., 2014) that were applied to propagation paths below the $0{ }^{\circ} \mathrm{C}$ level. For each radar measurement bin, the FL scheme assigns a score to each radar measurement. These scores are obtained by considering how the radar measurements fit the set of membership functions for a given hydrometeor class. The hydrometeor class with the highest score is assigned to each radar resolution volume. The results of the simulations of Fig. 1 have been used to tune the membership functions for graupel. Those of $Z_{\mathrm{dr}}$ and $K_{\mathrm{dp}}$ were set to account for both spheroidal and conical shaped graupel by allowing $Z_{\mathrm{dr}}$ to vary between -1 and $2 \mathrm{~dB}$ and $K_{\mathrm{dp}}$ to vary between -2 and $10^{\circ-1}$ similarly to Dolan et al. (2013) and Evaristo et al. (2013). Table 2 lists the parameters of the membership functions for the planes $Z_{h}-Z_{\mathrm{dr}}$ and $Z_{h}-K_{\mathrm{dp}}$ in comparison with those used in Baldini et al. (2005).

\subsubsection{Graupel IWC estimation}

The second important implication of the T-matrix simulation results concerns the estimation of graupel ice water content (IWC). The IWC of graupel (hereinafter $\mathrm{IWC}_{\mathrm{g}}$ ) was fitted to the simulated $Z_{h}$ (shown in Fig. 2 for spheroidal and conical shapes of graupel) by means of a power law relation of the form

$\mathrm{IWC}_{\mathrm{g}}=a Z_{h}^{b}$,

where $a=4.64 \times 10^{-4}, b=7.12 \times 10^{-1}$ for spheroid graupel and $a=4.70 \times 10^{-4}, b=6.89 \times 10^{-1}$ for conical graupel; $\mathrm{IWC}_{\mathrm{g}}$ is in $\mathrm{g} \mathrm{cm}^{-3}$ and $Z_{h}$ is in $\mathrm{mm}^{6} \mathrm{~m}^{-3}$. To assess the uncertainty of (2) we considered the normalized standard error (NSE) between the simulated $\mathrm{IWC}_{\mathrm{g}}$ obtained from (1) and the one estimated by (2). The NSE was 0.553 for speroidal and 0.523 for conical shapes, respectively. The normalized bias was 0.012 for spheroidal and 0.005 for conical shapes, indicating that (2) is unbiased. Since the coefficients of (2) for the two shapes of graupel were very similar, we simply used those found for spheroidal graupel. When applied to conical graupel, the NSE changed by less than $6 \%$.

\subsubsection{Radar data processing}

The basic steps listed below are applied to radar data acquired during the events considered in this study:

- selection of volumes with eight complete PPIs and total LINET strokes (both CG and IC) detected within the $5 \mathrm{~min}$ of each radar volume scan in the $120 \mathrm{~km}$ radius radar coverage area

- estimation of $0^{\circ} \mathrm{C}$ level using vertical profiling of LIRE soundings for each day

- estimation of $K_{\mathrm{dp}}$ from $\Phi_{\mathrm{dp}}$ using the finite difference method (Bringi and Chandrasekar, 2001)

- attenuation correction for $Z_{h}$ and $Z_{\mathrm{dr}}$ using linear relation of $K_{\mathrm{dp}}$ with specific attenuation and specific linear attenuation

- resampling of the polarimetric measurements to obtain a $1200 \mathrm{~m}$ resolution in range (i.e., 16 range bins)

- detection of graupel using the C-band radar FL HCA optimized for graupel

- estimation of columnar $\mathrm{IWC}_{\mathrm{g}}$ by vertically integrating the $\mathrm{IWC}_{\mathrm{g}}$ derived from (2) for each radar-sampled volume classified as graupel in the region that typically consists of a negative charging zone (vertical extension between -40 and $0^{\circ} \mathrm{C}$ ), i.e., the column of graupel above the $0^{\circ} \mathrm{C}$ level 
Table 2. Parameters of beta $Z_{h}-Z_{\mathrm{dr}}$ and $Z_{h}-K_{\mathrm{dp}}$ membership functions (Liu and Chandrasekar, 2000) for C-band and graupel identification ( $A$ is half-width, $M$ is the center, and $B$ is the slope of the beta functions). Columns denoted by "Opt" refer to the functions of the modified HCA scheme optimized for graupel identification.

\begin{tabular}{|c|c|c|c|c|c|c|c|c|c|c|c|c|c|c|c|}
\hline \multicolumn{4}{|c|}{$Z_{\mathrm{dr}}$} & \multicolumn{4}{|c|}{$Z_{\mathrm{dr}} \mathrm{Opt}$} & \multicolumn{4}{|c|}{$K_{d p}$} & \multicolumn{4}{|c|}{$K_{d p} \mathrm{Opt}$} \\
\hline$Z_{h}$ & $M$ & $A$ & $B$ & $Z_{h}$ & $M$ & $A$ & $B$ & $Z_{h}$ & $M$ & $A$ & $B$ & $Z_{h}$ & $M$ & $A$ & B \\
\hline 30 & 0.15 & 0.65 & 10 & 30 & 0.5 & 1.5 & 10 & 30 & -0.15 & 0.35 & 10 & 30 & 2.5 & 1.5 & 10 \\
\hline 35 & 0.25 & 0.75 & 10 & 35 & 0.5 & 1.5 & 10 & 35 & -0.1 & 0.4 & 10 & 35 & 2.5 & 2.5 & 10 \\
\hline 40 & 0.35 & 0.85 & 10 & 40 & 0.5 & 1.5 & 10 & 40 & 0.05 & 0.55 & 10 & 40 & 2.5 & 3.5 & 10 \\
\hline 45 & 0.5 & 1 & 15 & 45 & 0.5 & 1.5 & 10 & 45 & 0.5 & 1 & 15 & 45 & 2.5 & 4.5 & 10 \\
\hline 50 & 0.75 & 1.25 & 15 & 50 & 0.5 & 1.5 & 10 & 50 & 0.75 & 1.25 & 15 & 50 & 2.5 & 5.5 & 10 \\
\hline 55 & 1 & 1.5 & 15 & 55 & 0.5 & 1.5 & 10 & 55 & 1 & 1.5 & 15 & 55 & 2.5 & 6.5 & 10 \\
\hline
\end{tabular}

(a)
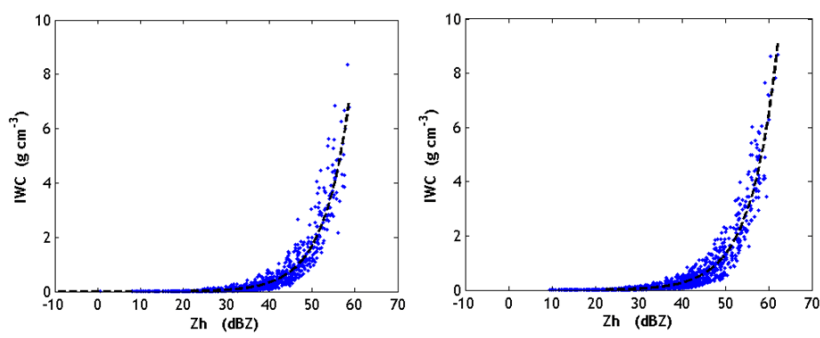

Figure 2. Scatter plots of C-band radar reflectivity and $\mathrm{IWC}_{\mathrm{g}}$. The left panel refers to spheroidal shape and the right panel to conical shape of graupel. Exponential fits (Eq. 2) are shown by black dashed curves.

- estimation of $\mathrm{IWC}_{\mathrm{g}}$ only performed beyond $25 \mathrm{~km}$ from the Polar 55C radar to detect cells above the ML and to avoid underestimation due to the cone of silence in the vicinity of the radar; calculation of the total amount of graupel (TAG, in $\mathrm{kg}$ ) by summing all the columnar $\mathrm{IWC}_{\mathrm{g}}$, each one multiplied by the area at the base of each column.

\subsection{2-D video disdrometer processing}

The 2-DVD data were filtered to remove spurious drops due to splashing or wind effects (Tokay et al., 2001). This resulted in removing $14 \%$ of the $2.2 \times 10^{6}$ drops collected during SOP1.1. Then, the observed diameters were partitioned into 50 bins with a constant width of $0.2 \mathrm{~mm}$. Ten drops in each $1 \mathrm{~min}$ spectra were requested to classify a spectrum as rain. A total of $47611 \mathrm{~min}$ RSDs were obtained.

Techniques for partitioning rain into stratiform or convective from point-wise disdrometer measurements collected at the ground may be based on properties of rain rate time series, such as intensity and time variability (e.g., Bringi et al., 2003; Marzano et al., 2010) or those based on RSD parameters (e.g., Bringi et al., 2009). In this study, the technique of Bringi et al. (2009), which classified rain minutes into convective, stratiform, and transition classes, was reformu-

lated to apply it to both radar measurements and disdrometer data. The latter was converted into DP radar measurements via T-matrix scattering computations. Simulations were performed for rain with the following assumptions: temperature of $20^{\circ} \mathrm{C}$, the shape-size model of Beard and Chuang (1987), and zero-mean Gaussian canting angle distribution with a standard deviation of $7.5^{\circ}$. The $1 \mathrm{~min}$ RSDs were classified as stratiform or convective using the criteria of Bringi et al. (2009) based on $N_{w}$ (i.e., the normalized intercept parameter) and $D_{0}$. The representation of the corresponding radar measurements at a specific frequency in the 2-D space defined by $Z_{h}$ and $Z_{\mathrm{dr}}$ leads to the identification of different precipitation regimes. Measurements collected by 2-DVD from 12 September to 12 November 2012 were analyzed at different frequencies (not shown). For C-band a threshold has been identified partitioning the $Z_{h}-Z_{\mathrm{dr}}$ plane into stratiform and convective regions (herein after $C / S$ threshold) as

$Z_{h}=36.86+0.84 Z_{\mathrm{dr}}$,

where $Z_{\mathrm{dr}}$ is in $\mathrm{dB}$ and $Z_{h}$ in dBZ. The results of the classification and their relation with other measurements available are presented and discussed in Sect. 5.2.

\section{Data set description}

Eleven convective precipitation events were selected, with both radar and lightning measurements available (from 3 September to 6 November 2012, while 2-DVD measurements over the Sapienza site were continuously available from 12 September to 12 November 2012). Six of these events were considered as Intense Observing Periods (IOPs) during the HyMeX SOP 1.1. The 2-DVD detected $4761 \mathrm{~min}$ of rain: $93.3 \%$ of this was classified as stratiform and $6.7 \%$ was classified as convective rain. Events with the highest percentage of convective minutes occurred on 13 September, 12, and 15 October 2012, when 10.2, 15.6, and $28.6 \%$ of minutes were classified as convective, respectively. The total number of strokes registered in $24 \mathrm{~h}$ within the $120 \mathrm{~km}$ radar range was 3621,7011 , and 3388 for the 13 September, 12, and 15 
Table 3. Dates for which both radar and LINET data are simultaneously available. Second and third columns: HyMeX SOP 1.1 IOP number (with availability of the F20 flights), and the target area (TA) involved in the IOP. Fourth and fifth columns: stratiform $(S)$ and convective $(C)$ minutes measured by 2-DVD over the Sapienza site. Sixth column: number of LINET strokes that occurred during Polar $55 \mathrm{C}$ observations and (in parentheses) the number of strokes in $24 \mathrm{~h}$. Seventh column: $0^{\circ} \mathrm{C}$ level height (in meters). Last column: mode of the distance to the radar of the peak of $\mathrm{IWC}_{\mathrm{g}}$. NA represents data that are not available.

\begin{tabular}{lcrrrrrr}
\hline Date & IOP & TA & 2-DVD/S & 2-DVD/C & Strokes & ML $(\mathrm{m})$ & Mode $(\mathrm{km})$ \\
\hline 3 September 2012 & & & NA & NA & $195(5166)$ & 3568 & $84-96$ \\
4 September 2012 & & NA & NA & $1202(3814)$ & 3328 & $84-96$ \\
5 September 2012 & & NA & NA & $941(2181)$ & 3466 & $84-96$ \\
13 September 2012 & 2 & NEI-LT & 342 & 38 & $3621(6594)$ & 3716 & $72-84$ \\
9 October 2012 & & & 15 & 0 & $220(273)$ & 3713 & $48-60$ \\
11 October 2012 & 12A & LT-CI & 0 & 0 & $28(32)$ & 3446 & $72-84$ \\
12 October 2012 & 12A & LT-CI & 180 & 71 & $7011(8909)$ & 3402 & $84-96$ \\
14 October 2012 & & & 0 & 0 & $4(122)$ & 3060 & $84-96$ \\
15 October 2012 & 13 (F20) & LT-CI-NEI & 157 & 31 & $3388(6765)$ & 2985 & $36-48$ \\
26 October 2012 & 16A \& C(F20) & LT-CI-NEI & 222 & 23 & $761(1434)$ & 3150 & $96-108$ \\
27 October 2012 & 16A \& C & LT-CI-NEI & 82 & 2 & $14(5078)$ & 3957 & $96-108$ \\
\hline
\end{tabular}

October, respectively (Table 3 ). These three events, associated with three IOPs with the most intense precipitation, are described and analyzed in detail.

\subsection{September 2012 case study}

This case occurred during the IOP2 (12-13 September 2012) that mainly involved NEI and LT sites, while intense precipitation also occurred in CI. During the morning of 12 September, a cold front extending from northern Germany to the northern Alps occurred, with an associated trough moving toward Italy, and then evolving into a cut-off low between Corsica and CI in the afternoon of 13 September. Concerning central southern Italy, most of the rainfall activity was located in the Naples area, while scattered deep convection occurred over the CI site.

Radar data collected by the Polar 55C radar during the event were used to monitor the evolution of the convective activity. Figure $3 \mathrm{a}-\mathrm{c}$ show PPIs of horizontal equivalent reflectivity factor collected by the Polar $55 \mathrm{C}$ at $1.6^{\circ}$ elevation angle during three phases of the precipitation event on 13 September 2012. A maximum radar range of $120 \mathrm{~km}$ was used. LINET strokes are superimposed on radar observation. At 20:00 UTC the initial stage of a convective cell (a high reflectivity area with few strokes superimposed) can be observed $80 \mathrm{~km}$ south of Polar 55C. One hour later, this cell developed and covered a larger high reflectivity area, with 30 strokes superimposed, while at 22:30 UTC, this cell splits into a number of cells covering a wide area, moving southward, away from the radar. Coincident Meteosat Second Generation (MSG) SEVIRI infrared (IR) images at $10.8 \mu \mathrm{m}$, providing the whole view of the system beyond the radar range, are shown in Fig. 3d-f with the LINET strokes superimposed. The intense convective system developed over the Tyrrhenian Sea, moved, and extended eastward, entering the
Polar 55C radar range after 20:00 UTC. The MSG 10.8 $\mu \mathrm{m}$ brightness temperatures associated with the strokes are below $-50{ }^{\circ} \mathrm{C}$ indicating a cloud top height of around $10 \mathrm{~km}$

\subsection{October 2012 case study}

This event, associated with a secondary trough over the central Mediterranean Sea, occurred during IOP12a and carried heavy precipitation over the CI site, mainly Lazio and Umbria regions, on 11-12 October 2012. This event started over the Tyrrhenian Sea, where several MCSs (mesoscale convective systems) developed during the night of 11 October. Convective systems reached central Italy in the early morning of 12 October, with heavy precipitation over the northern part of Lazio and Umbria regions. Rain was not persistent, but the maximum cumulated rainfall registered in $\mathrm{CI}$ exceeded $150 \mathrm{~mm}$ in $6 \mathrm{~h}$. This event mostly occurred outside of the Polar 55C radar coverage as shown in the MSG IR images (Fig. 4d-f). At 04:30 UTC the most intense portion of the system, where LINET strokes were detected, was over the Tyrrhenian Sea, to the southwest of the radar. Polar 55C (Fig. $4 \mathrm{a}-\mathrm{c}$ ) was able to observe only part of the MCS and beyond $80 \mathrm{~km}$ distance. One hour and $30 \mathrm{~min}$ later, the MCS moved to the south and farther away from the radar $(100 \mathrm{~km})$.

\subsection{October 2012 case study}

This case study is part of the IOP13, which took place on 14 and 15 October 2012 across a vast area in the western Mediterranean including also all three hydrometeorological sites in Italy (see Ferretti et al., 2014). On these days, a severe weather warning was issued for central Italy, particularly for Rome, by the regional weather service. The precipitation event was associated with a trough that deepened significantly over the northern Tyrrhenian Sea, pushed a frontal 
(a)

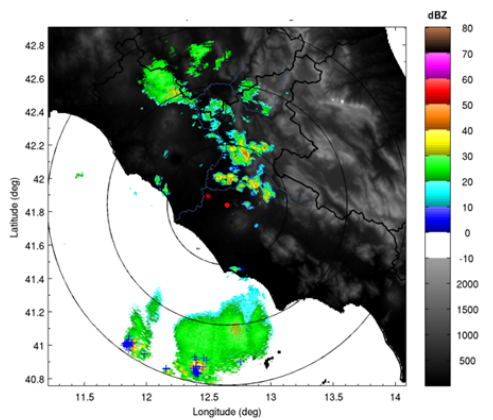

(d)

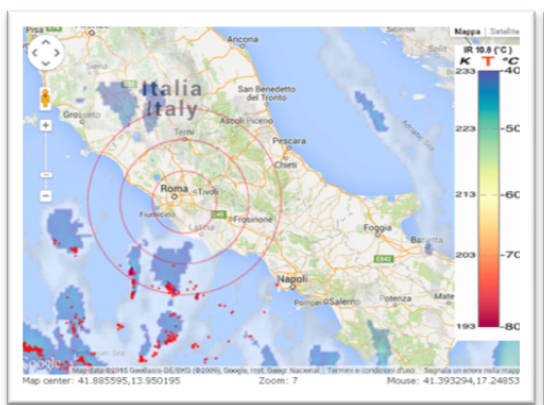

(b)

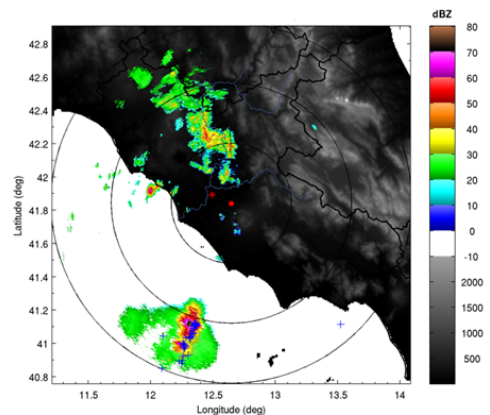

(e)

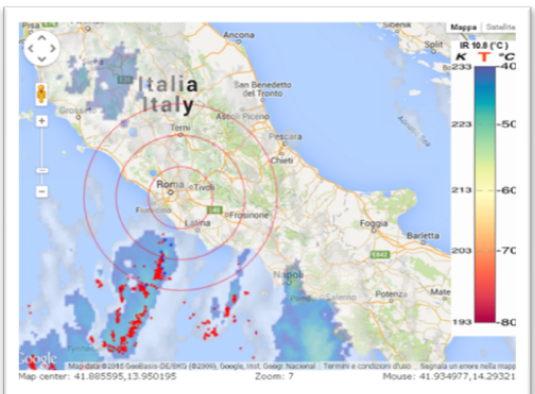

(c)

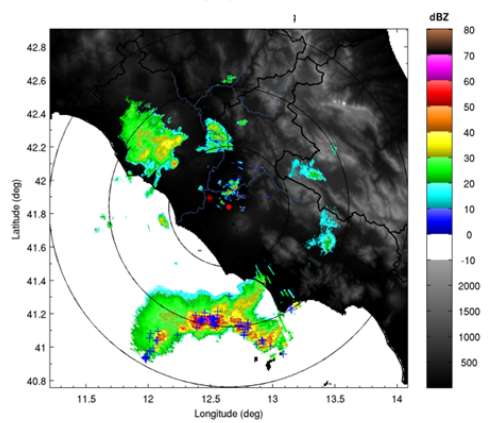

(f)

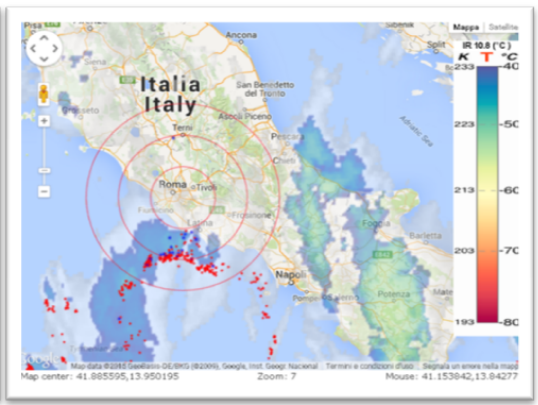

Figure 3. Polar 55C $Z_{h}$ (1.6 of elevation angle) at 20:00 UTC (a), 21:00 UTC (b), and 22:30 UTC (c) on 13 September 2012. The strokes registered in $5 \mathrm{~min}$ are superimposed (blue cross). In (d-f) panels, the corresponding infrared (IR) MSG images at $10.8 \mu \mathrm{m}$ are shown with the LINET strokes that occurred in $15 \mathrm{~min}$ (CG in red dots; IC in blue dots) and Polar 55C range rings at 40, 80, and 120 km (d-f panels were generated using the MAMS tool developed at ISAC-CNR, Petracca et al., 2013).

(a)

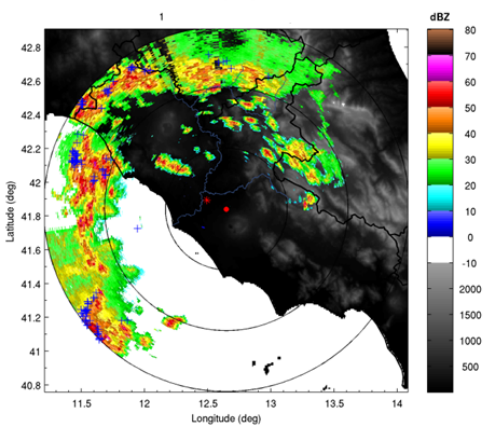

(d)

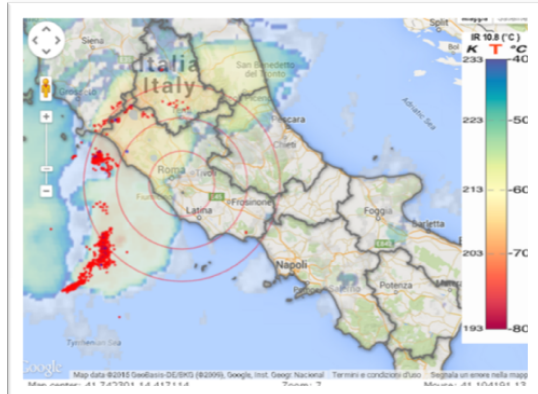

(b)

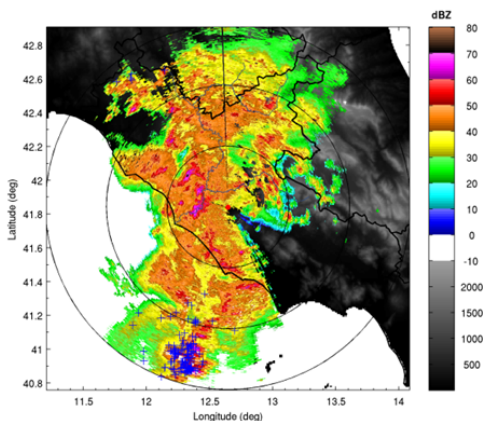

(e)

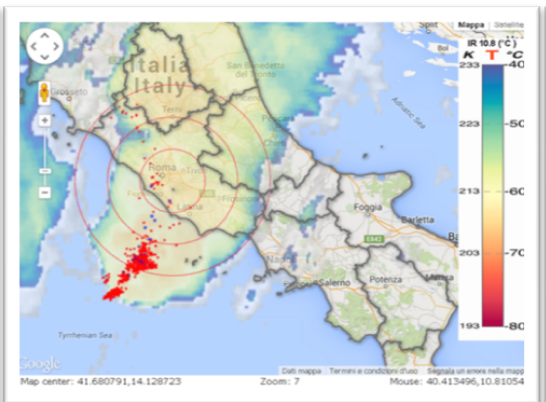

(c)

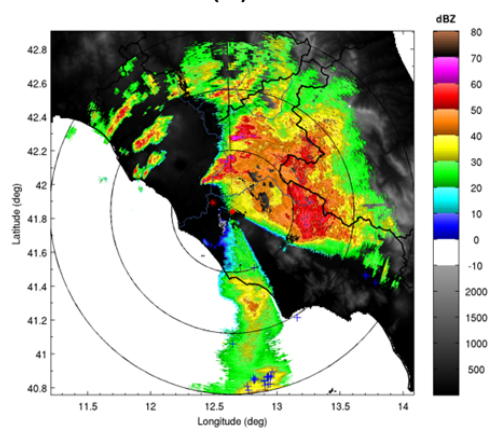

(f)

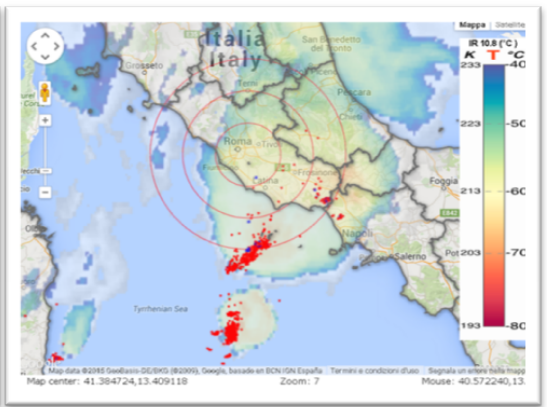

Figure 4. As in Fig. 3 for 12 October 2012 at 03:00 UTC (a, d), 04:30 UTC (b, e), and 06:00 UTC (c, f). 
(a)

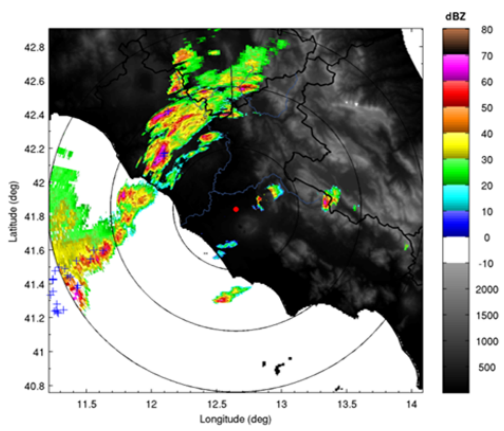

(d)

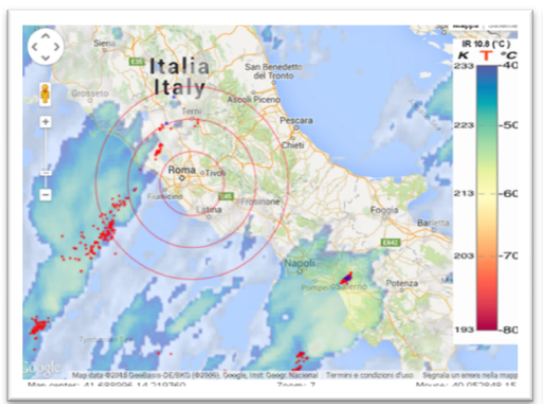

(b)

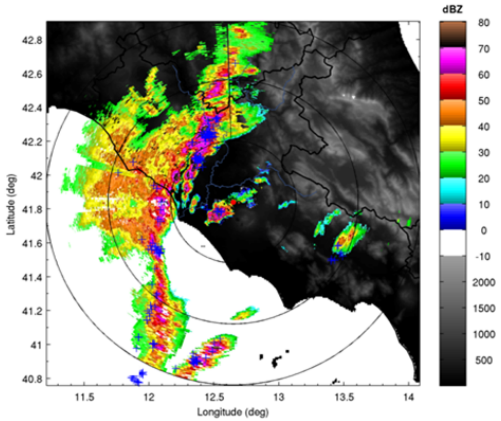

(e)

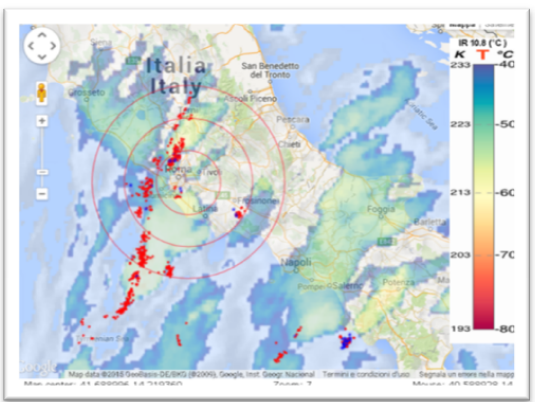

(c)

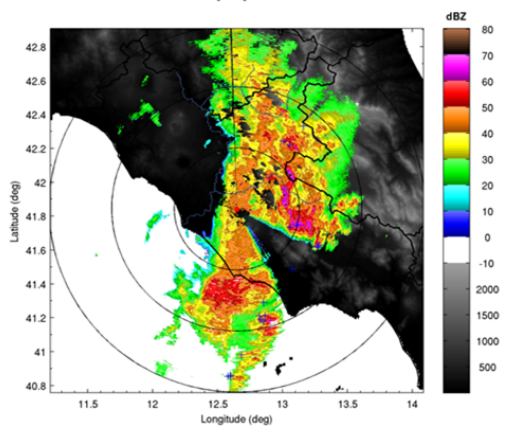

(f)

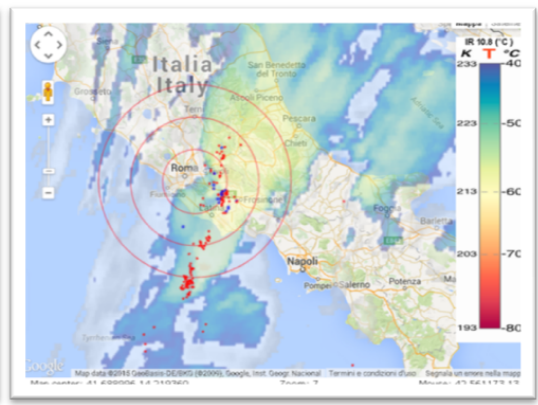

Figure 5. As in Fig. 3 for the 15 October 2012 at 16:00 UTC (a, d), 17:30 UTC (b, e), and 19:10 UTC (c, f).

system eastward, and advected moist air from the Tyrrhenian Sea inland to fuel deep convection on the Tyrrhenian coast, west of Rome. The synoptic-scale system moved rapidly to the east and triggered a line of convection that crossed the western half of central Italy from north to south within a few hours (see also Federico et al., 2014). Most of the precipitation produced by this system occurred in the late afternoon of 15 October across the western part of $\mathrm{CI}$ and on the western slopes of the Apennines. The total rainfall amount recorded in Rome was weaker than predicted - the highest daily amount recorded within the historic area of Rome was $35 \mathrm{~mm}$ by the operational rain gauge in Eleniano (close to the Sapienza site). A maximum rainfall rate of $124 \mathrm{~mm} \mathrm{~h}^{-1}$ was recorded by the Sapienza 2-DVD at 18:09 UTC. Three phases of the precipitation event are shown by the PPIs of $Z_{h}$ in Fig. 5a-c. At 16:00 UTC a few convective cells were detected by Polar 55C in the northwest sector (Fig. 5a), while the lightning activity within the radar coverage area was low (14 strokes detected by LINET in 5 min within the radar coverage circular area of $120 \mathrm{~km}$ radius). By 17:30 UTC, a line of convective cells with radar reflectivity above $50 \mathrm{dBZ}$ had developed and the lightning activity became more intense (Fig. 5b). LINET detected 227 strokes in 5 min within the radar coverage area, mostly co-located with the higher radar reflectivity areas (Fig. 5b). The convective activity weakened after 19:00 UTC (Fig. 5c), and most of the precipitation detected by the radar exhibited stratiform characteristics, especially over Rome, with drastically weakened lightning activ- ity (37 strokes were recorded in 5 min over the radar coverage area). MSG IR images with LINET strokes superimposed (Fig. 5d-f) confirm that the most intense portion of the line of convection occurred within the radar coverage area.

\section{Results}

\subsection{Dual-polarization radar analysis and lightning activity}

The RHIs collected by Polar 55C along the azimuth of the Sapienza site $\left(293^{\circ}\right)$ during the intense precipitation phases enabled us to test the FL-based HCA results and the $\mathrm{IWC}_{\mathrm{g}}$ estimation. An example of the classification output from the RHI performed on 15 October 2012 at 17:55 UTC is shown in Fig. 6a. Radar measurements were resampled, averaging four consecutive range bins to a range resolution of $300 \mathrm{~m}$. The hydrometeor classes identified by the HCA are rain, dry snow, wet snow, graupel and small hail, hail, and a mix of rain and hail. Two intense convective cells were present around 12 and $25 \mathrm{~km}$ from the radar in the vicinity of Rome at 17:55 UTC. The closest one was characterized by the presence of graupel from the ground to a height of $8 \mathrm{~km}$, while the second one was characterized by graupel (up to $6 \mathrm{~km}$ ), as well as hail, and hail mixed with other hydrometeors, also in proximity of the surface. These cells mostly had $Z_{h}$ values of $40 \mathrm{dBZ}$, reaching 50 and $55 \mathrm{dBZ}$ in the convective cores. Comparing these RHI classification results with those ob- 
Table 4. Coefficients for the linear regression $(y=a x+b)$ and coefficient of determination $\left(R^{2}\right)$ obtained for the three case studies shown in Fig. 8. The first three parameters concern the TAG obtained from the new scheme of HCA, while the next three parameters from TAG are obtained by the former HCA.

\begin{tabular}{lcccccc}
\hline Date & $a$ & $b$ & $R^{2}$ & $a$ & $b$ & $\mathrm{R}^{2}$ \\
\hline 13 September 2012 & $1.63 \times 10^{6}$ & $2.86 \times 10^{6}$ & 0.506 & $1.75 \times 10^{6}$ & $3.71 \times 10^{6}$ & 0.478 \\
12 October 2012 & $1.23 \times 10^{6}$ & $1.03 \times 10^{7}$ & 0.824 & $1.82 \times 10^{6}$ & $2.68 \times 10^{7}$ & 0.807 \\
15 October 2012 & $5.77 \times 10^{6}$ & $2.71 \times 10^{7}$ & 0.856 & $6.31 \times 10^{6}$ & $3.66 \times 10^{7}$ & 0.850 \\
\hline
\end{tabular}

(a)

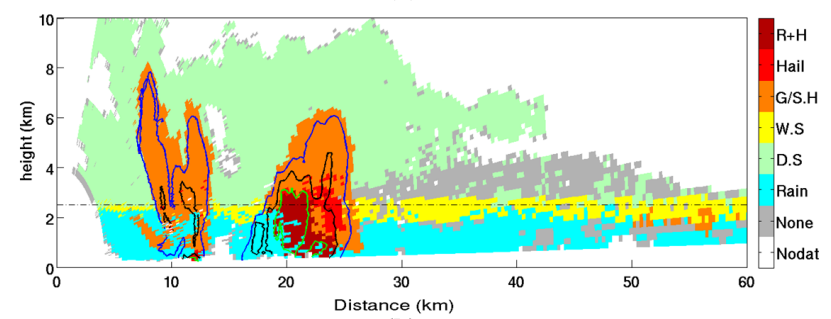

(b)

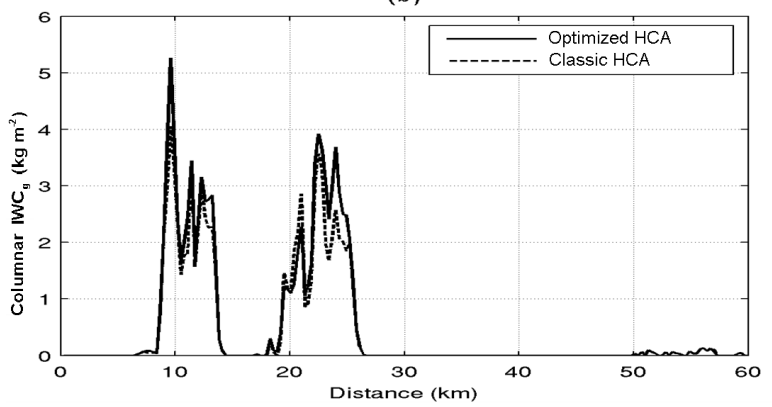

Figure 6. Polar 55C RHI scan collected at 17:55 UTC on 15 October 2012 for the azimuth at $293^{\circ}$ along the Sapienza site with resampled radar measurements at a $300 \mathrm{~m}$ range resolution. (a) FL HCA optimized for graupel, with the color bar as follows: white denotes no data, gray denotes data that are not classified, light blue denotes rain, green denotes dry snow, yellow denotes wet snow, orange denotes graupel and small hail, red denotes hail, and dark red denotes a hail/rain mix. The $Z_{h}$ contours at $40 \mathrm{dBZ}$ (blue solid line), $50 \mathrm{dBZ}$ (black solid line), and $55 \mathrm{dBZ}$ (green solid line) are superimposed. The black dashed-dotted line shows the $0^{\circ} \mathrm{C}$ level. (b) Columnar $\mathrm{IWC}_{\mathrm{g}}$ corresponding to the RHI obtained from the HCA optimized for graupel (black solid line) and from the classical HCA (black dashed line).

tained using the scheme presented in Baldini et al. (2005), the new scheme adds $8 \%$ of pixels classified as graupel. Figure $6 \mathrm{~b}$ shows the columnar $\mathrm{IWC}_{\mathrm{g}}\left(\right.$ in $\mathrm{kg} \mathrm{m}^{-2}$ ) for each range bin for the two classification schemes. The new scheme estimates from 2 to $10 \%$ more columnar $\mathrm{IWC}_{\mathrm{g}}$, along the range distance. At this time (within 2 min around the RHI scan) LINET detected 18 strokes within a $10 \mathrm{~km}$ radius of the peaks of the columnar $\mathrm{IWC}_{\mathrm{g}}$. Although the RHI scanning mode provides better vertical resolution than PPI volume scans, the RHI measurements cover a very narrow azimuthal slice (i.e., only the $1^{\circ}$ beam width), which makes it difficult to relate the estimated graupel mass content to the lightning occurring across a wider horizontal area. Therefore, volume scans processed as described in Sect. 3.1.3 were used to consider the entire $120 \mathrm{~km}$ radar coverage area and to have data every 5 min.

To investigate the relationship between the graupel mass and lightning activity, the columnar $\mathrm{IWC}_{\mathrm{g}}$ was calculated for nearly the entire radar coverage area and compared with the number of strokes (CG and IC) detected by the LINET. Figure 7 shows an example of columnar $\mathrm{IWC}_{\mathrm{g}}$ in three PPI scans of 15 October. We found the relative peaks in lightning activity tended to follow peaks in columnar $\mathrm{IWC}_{\mathrm{g}}$. Figure $7 \mathrm{a}$ shows that columnar $\mathrm{IWC}_{\mathrm{g}}$ was less than $3 \mathrm{~kg} \mathrm{~m}^{-2}$ during the initial stage of the event at 16:00 UTC when only a few coincident strokes were detected, indicating early convective development in the radar coverage area. At 17:30 UTC (Fig. 7b) the line of cells oriented northeast to southwest were characterized by high values of columnar $\mathrm{IWC}_{\mathrm{g}}$ (up to $5 \mathrm{~kg} \mathrm{~m}^{-2}$ ) and a high number of lightning strokes overlapping quite well with the line of convective cells. Figure $7 \mathrm{c}$ shows the columnar IWC $_{\mathrm{g}}$ at 19:20 UTC, when convection had weakened (in the northwestern part of Rome). Just a few strokes and low columnar $\mathrm{IWC}_{\mathrm{g}}$ were found southeast of Rome.

A quantitative relationship between the total number of LINET strokes (both CG and IC) and the TAG was determined. Figure 8a shows the scatter plot between TAG and the total number of LINET strokes in the coverage area of the Polar 55C for the three case studies (different colors are used for each case study). The parameters for the regression are shown in Table 4. A good linear correlation is found for the two case studies that occurred in October, while a worse correlation is found on 13 September (Table 4). Furthermore, for all cases, a higher correlation (higher values of $R^{2}$ ) between TAG and strokes is obtained when the new HCA is used for graupel detection (Table 4). Observing the scatter plot in Fig. 8a, it is evident that the behavior for 15 October is different from that for 13 September and 12 October. The slopes of linear regression for the latter two dates are very similar and the TAG is underestimated by $70 \%$ if the fit to 15 October is used as a reference. In order to compare these results to model outputs and to other studies, we have grouped strokes into flashes using the Yair et al. (2014) approach (where the spatial range depends on the lightning detection network 
(a)

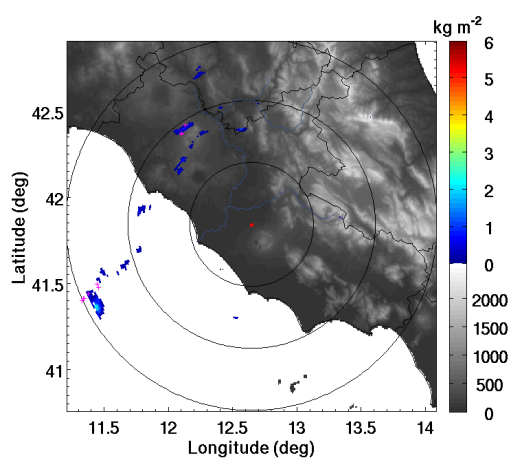

(b)

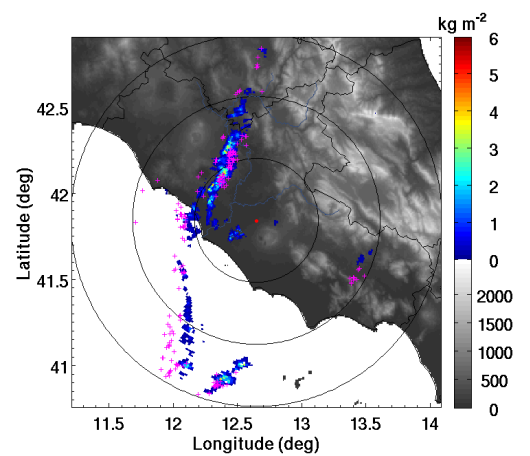

(c)

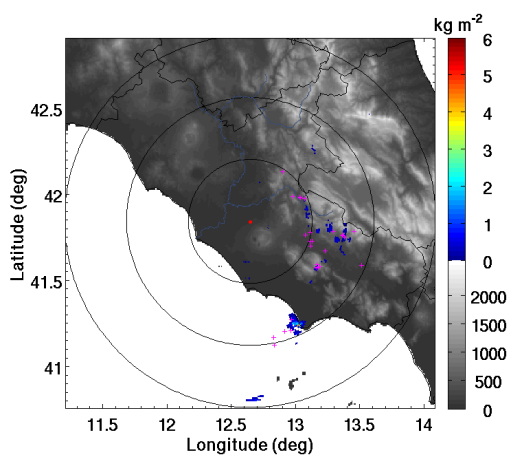

Figure 7. The columnar $\mathrm{IWC}_{\mathrm{g}}$ estimated from Polar 55C at 16:00 UTC (a), 17:30 UTC (b), and 19:20 UTC (c) on the 15 October 2012. Strokes detected by LINET network are represented by the magenta crosses.

characteristics). Strokes recorded in $1 \mathrm{~km}^{2}$ within $0.2 \mathrm{~s}$ were grouped into one flash. Furthermore, we have calculated a mean value of the columnar $\mathrm{IWC}_{g}$ for each radar volume (computed every $5 \mathrm{~min}$ ), dividing the TAG by the mean total area covered by graupel (in $\mathrm{km}^{2}$ ). This quantity was related to the flash number density (number of flashes $\mathrm{km}^{-2}$ registered in $5 \mathrm{~min}$ ) and the results for the three case studies are shown in Fig. 8b. The different behavior for 15 October and the other two cases found in Fig. 8a is still evident. The minimum threshold linear function of FO13 and the linear function found by PE05 over land (properly converted to match the units used for this plots) are also shown. The data of the 15 October case (and its best fit) are in agreement with the PE05 linear relation (obtained by TRMM measurements) and are (for the most part) above the columnar $\mathrm{IWC}_{\mathrm{g}}$ minimum threshold found by FO13 for lightning occurrence. However, for the 13 September and 12 October, the linear functions have a lower slope; i.e., for these two cases, the columnar $\mathrm{IWC}_{\mathrm{g}}$ associated with a given flash number density is lower than FO13 model or TRMM observations. Different causes could contribute to this result and can be related to (i) radar measurement geometry and to (ii) the nature of the convective event.

Concerning (i), the radar measurements for the three events show that the areas of intense precipitation, where graupel is detected, are at different distances from the Polar 55C. On 13 September and 12 October, Polar 55C observes the edge of the MCS's core located over the Tyrrhenian Sea (see Figs. 3 and 4). The areas with most intense precipitation (and LINET strokes) were mostly farther than $80 \mathrm{~km}$ (the mode of the distance of the maximum columnar $\mathrm{IWC}_{\mathrm{g}}$ was located over $70 \mathrm{~km}$ from the radar, as shown in the last column of Table 3). At such distance, the radar beam becomes very wide $\left(1^{\circ}\right.$ of beamwidth corresponds to a sample volume of about $1.8 \mathrm{~km}$ height at $80 \mathrm{~km}$ ), implying that backscattering is generated by larger volumes more likely filled by different types of hydrometeors, and induc- ing possible miss-detection of graupel by the FL HCA. Another source of underestimation of $\mathrm{IWC}_{\mathrm{g}}$ by radar can be attributed at the different height of the $0{ }^{\circ} \mathrm{C}$ isothermal (freezing level) estimated by radiosounding. For the 15 October 2012 it was estimated at about $2.9 \mathrm{~km}$, while for the other two cases it was above $3.4 \mathrm{~km}$ (Table 3 ). Since the $\mathrm{IWC}_{\mathrm{g}}$ is calculated for the radar beams above the $0^{\circ} \mathrm{C}$ level, the higher the freezing level is, the lower the depth of the column considered for the $\mathrm{IWC}_{\mathrm{g}}$ computation is. In order to quantify such an effect on the graupel mass estimation we have performed some simulations, considering a homogeneous $6 \mathrm{~km}$ graupel column (from the ground) and using different freezing level heights. The columnar $\mathrm{IWC}_{g}$ can be reduced up to $17 \%(30 \%)$ for a freezing level at $3.4 \mathrm{~km}(3.9 \mathrm{~km})$ with respect to the value obtained for a $2.9 \mathrm{~km}$ freezing level. It is therefore likely that the 15 October 2012 convective cells occurred with better radar observational conditions for the detection and estimate of graupel mass than the other two cases, and that the environmental conditions for that case favored the presence of graupel at lower levels. Concerning (ii), the electrification process links the microphysical and kinematic evolution of storms with the evolving characteristics of storm charge and lightning. Storms with a large updraft mass flux and large graupel volume typically produce large flash rates (e.g., Wiens et al., 2005; Deierling and Petersen, 2008). According to the non-inductive charging mechanism (see Saunders, 1993), graupel is only one ingredient required for charge generation in clouds. The other key feature is the size and strength of the updraft (e.g., Deierling and Petersen, 2008). The total lightning flash rate has been shown to be tied to the flux of hydrometers within the cloud (Blyth et al., 2001; Latham et al., 2004; Weins et al., 2005; Deierling et al., 2008). More specifically, the downward flux of graupel through a region of significant updraft $\left(>5 \mathrm{~m} \mathrm{~s}^{-1}\right)$ at altitudes where ice crystals and supercooled droplets coexist $\left(-5<\mathbf{T}<-40^{\circ} \mathrm{C}\right)$ regulates the total flash rate (Weins et al., 2005; Deierling et al., 2008). Therefore, we cannot 

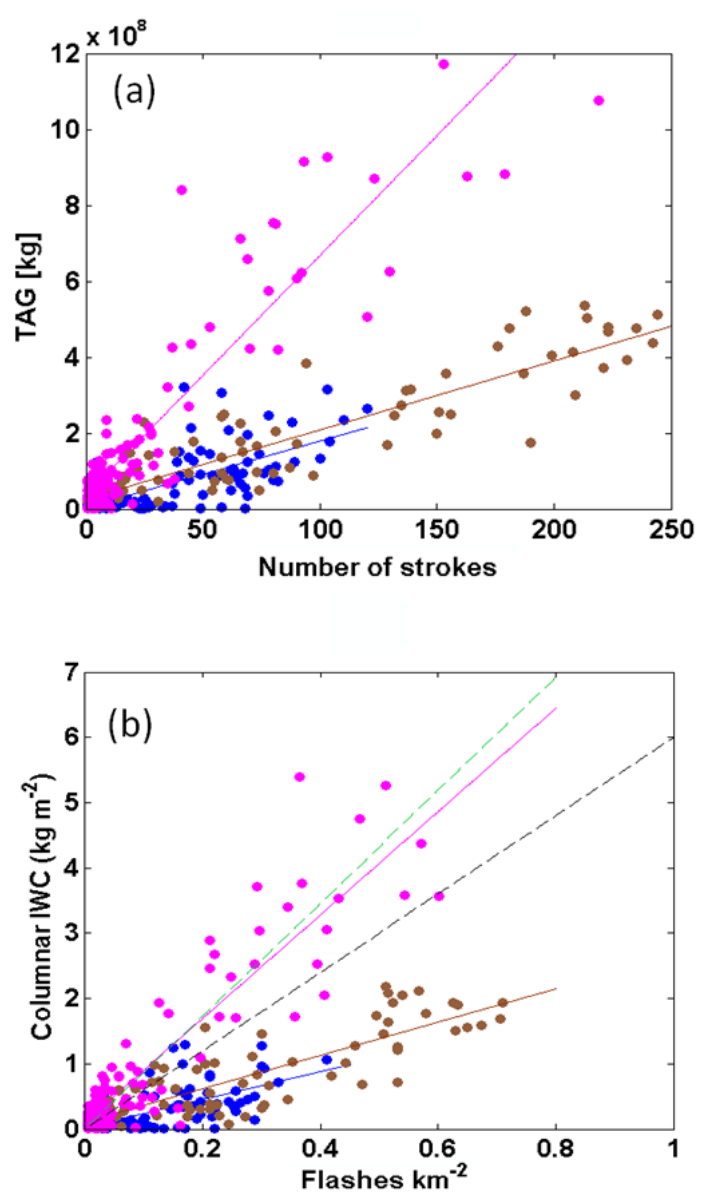

Figure 8. (a) The total number of strokes detected (in $5 \mathrm{~min}$ ) by LINET in the Polar 55C coverage area in relation to TAG (computed every $5 \mathrm{~min}$ ) on 13 September 2012 (blue), 12 October 2012 (brown), and 15 October 2012 (magenta); (b) flash density in relation to the mean columnar IWC $_{\mathrm{g}}$ (each computed every $5 \mathrm{~min}$ for the same days). All points for each day are fitted with linear regression (solid line). In (b) the black dashed line is the threshold found by FO13 and the green dashed line is the linear relation found by PE05 over land.

solely use TAG to fully explain the differences in the total number of strokes amongst the three case studies. Considering the flux hypothesis (Blyth et al., 2001; Latham et al., 2004), we can say that the differences in TAG for a similar total number of strokes detected by LINET (Fig. 8a) suggest that there were differences in the updraft characteristics between the two type of events. For the 15 October event (magenta dots in Fig. 8a) with the highest amount of graupel, the updraft does not need be as strong/large through the charging zone (i.e., $-5<\mathbf{T}<-30^{\circ} \mathrm{C}$ ) to produce observed lightning activity similar to the other events. For the 12 October (or 13 September) event, with a lower amount of graupel, a stronger/larger updraft through the charging zone was required to produce similar lightning activity as 15 October. However, measurements of the updraft at altitudes above
Table 5. Number of occurrences (from 16:00 to 20:25 UTC on 15 October) of the different kind of LINET strokes (second column), and $R^{2}$ of the linear correlation between strokes and the total amount of $\mathrm{IWC}_{\mathrm{g}}$.

\begin{tabular}{lrc}
\hline Strokes & Occurrence & $R^{2}$ \\
\hline- CG & 1834 & 0.73 \\
+CG & 732 & 0.66 \\
IC & 518 & 0.48 \\
Total & 3084 & 0.86 \\
\hline
\end{tabular}

$-5^{\circ} \mathrm{C}$ (not available from ground instruments deployed during SOP1.1 in CI) would be required to validate such conclusions.

Although different regimes were found in the relation between TAG and the number of strokes (or columnar $\mathrm{IWC}_{\mathrm{g}}$ and flash number density), the rather good linear fit confirms the linear relations found in other studies. In particular, the relation for the case of 15 October is in good agreement with both TRMM measurements and model results, supporting the hypothesis that measurements for this case were taken in optimal conditions with respect to the radar geometry of acquisition.

Finally, the ability of the LINET network to discriminate between CG and IC strokes, and to determine the polarity associated with CG strokes, was analyzed. Severe storms appeared to be significant producers of $+\mathrm{CG}$ lightning (Carey and Rutledege, 2003). Among the three case studies analyzed, on the 15 October $201230 \%$ of CG strokes were positive, while for the other two case studies + CG strokes were around $20 \%$. Considering the relation between TAG, and IC, $+\mathrm{CG}$ and $-\mathrm{CG}$, the results are summarized in Table 5 for the 15 October case study. Most of the registered strokes were -CG and they increase with TAG (linear regression yields an $R^{2}$ of 0.73 ), but the number of the IC strokes detected was lower and more poorly correlated with TAG $\left(R^{2}=0.48\right)$. This suggests that the IC strokes are not well correlated to the graupel aloft but could be better correlated with other hydrometeors such as hail at the surface. In fact, occurrence of a high number of ICs during severe weather events such as tornadoes and large hail at the ground has been documented (Cummins et al., 2000). However, it is worth noting that the LINET network detects more CG than IC strokes, and the lower correlation could also be due to the large baseline between sensors near the coast (Zinner et al., 2013), which can cause a reduced detection efficiency and significant impact on the detection of weak ICs. In particular Formenton et al. (2013) showed higher LINET performances in ICs' detection in the area of Munich compared to the area of Rome where baseline is larger. Since the best correlation was found for the $-\mathrm{CG}$, the time evolution of the graupel total mass and $-\mathrm{CG}$ was examined (Fig. 9). The increasing and decreasing trends of $-\mathrm{CG}$ lightning activity tend to fol- 


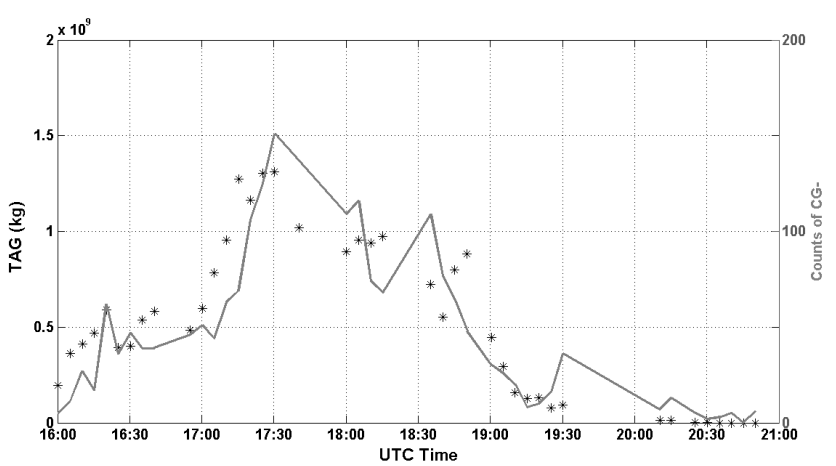

Figure 9. The time evolution of TAG (black stars and $y$ axis on the left side) and the $-\mathrm{CG}$ stroke counts (solid line and $y$ axis on the right side) that occurred on 15 October 2012 within the Polar 55C coverage area.

low that of the total mass of graupel, in agreement with the findings of López and Aubagnac (1997).

Some general considerations can be obtained from the results shown: (i) the linear correlation between TAG and the number of strokes (total and -CG) supports the theory for which the amount of graupel aloft, often associated with the negative charge in the clouds (Saunders, 1993), is directly related to the mechanism of lightning production, and (ii) the linear relation between the columnar $\mathrm{IWC}_{\mathrm{g}}$ and flash number density found using radar observations for the 15 October 2012 is in agreement with results obtained by PE05 for TRMM measurements and with the model results obtained by FO13. This important finding could be exploited for applications involving lightning data simulation and/or assimilation in NWP models in order to improve the forecast of the convection (Lynn et al., 2012; Federico et al., 2014).

\subsection{Multi-sensor analysis over the Sapienza site}

The 47611 min RSDs were classified as stratiform and convective using the criterion described in Sect. 3.2 and compared with radar measurements observed over the Sapienza site for all the data set. Furthermore, their relation with lightning activity was assessed. The scatter plot $Z_{h}-Z_{\mathrm{dr}}$ computed for all the $1 \mathrm{~min}$ RSD is shown in Fig. 10 (the threshold separating convective from stratiform regimes is plotted as a black solid line). It is worth noting that most stratiform minutes are below the $C / S$ threshold detected by 2-DVD and some of these $(7.5 \%)$ are just above, around the threshold. The Polar 55C radar reflectivities and differential reflectivities (colored stars) measured at a $1.6^{\circ}$ elevation angle and averaged over four consecutive $75 \mathrm{~m}$ range bins above the Sapienza site are also shown in Fig. 10. A $C / S$ classification method based on the detection of the melting layer signature corresponding to the standard deviation of $Z_{\mathrm{dr}}$ (Baldini and Gorgucci, 2006) was adopted. Six convective minutes are detected by Polar 55C and one of these is found just below the $C / S$ threshold. Results confirm that radar classification of

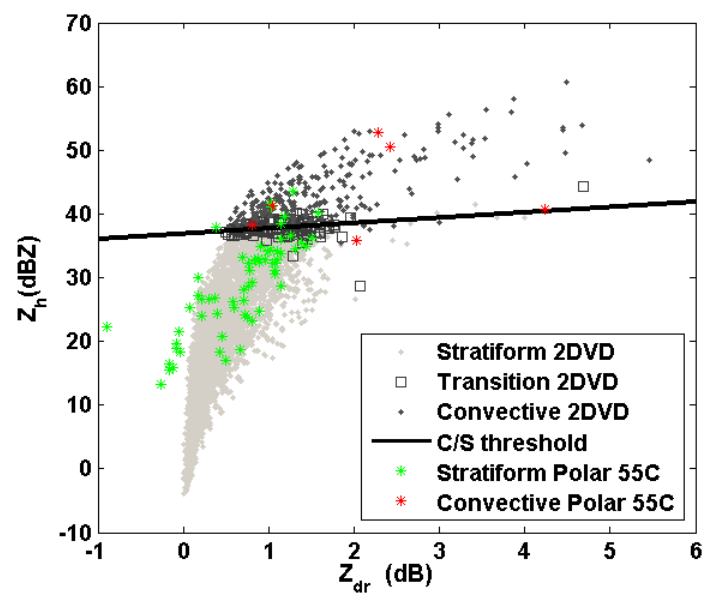

Figure 10. Plot of the $Z_{h}$ and $Z_{\mathrm{dr}}$ obtained from the disdrometer measured RSD through electromagnetic simulation for all the data sets collected by 2-DVD (gray markers). The different gray shades are based on the $C / S$ classification of Bringi et al. (2009). The $C / S$ threshold is shown by Eq. (3). The rainy minutes above the $C / S$ threshold are classified as convective, and the ones below as stratiform. Colored stars denote the Polar 55C measurements collected over the Sapienza site (elevation $1.6^{\circ}$ ) for all the databases classified according to Baldini and Gorgucci (2006).

convective vs. stratiform from Baldini and Gorgucci (2006) is in fairly good agreement with the $C / S$ threshold from $Z_{h}-Z_{\mathrm{dr}}$ (Eq. 3).

The RSD averages over the convective minutes of the three cases are shown in Fig. 11. The shape of lines of 13 September and the 12 October are very similar, while, concerning the 15 October, the concentration of larger drops $(D>3 \mathrm{~mm})$ is greater than for the other two cases. This different behavior highlights the different type of convective precipitation events (actually, this concerns only the portion of the event occurring over Rome). In fact, on 15 October, the event observed in Rome was more intense than the other two and was characterized by more intense lightning activity: 156 strokes were detected by LINET in $1 \mathrm{~min}$ and within $10 \mathrm{~km}$ of the Sapienza site on 15 October, while 43 and 7 strokes were measured on 13 September and 12 October, respectively.

For this reason, further analysis involving LINET and 2DVD will focus only on the 15 October case study. For this case, the time series of $1 \mathrm{~min}$ radar reflectivity factor simulated from the 188 RSDs compared with Polar 55C radar reflectivity measurements are shown in Fig. 12. In addition, the resulting $C / S$ classification and the lightning activity (within $10 \mathrm{~km}$ of the Sapienza site) is also shown. The $C / S$ classification using 2-DVD threshold applied to the radar measurements was in agreement with the classification from the disdrometer measurements. Between 17:50 and 18:20 UTC, a large number of strokes were detected by LINET, when rain was classified as convective. However, convective rain was also found before 17:00 UTC, but just 
Table 6. Contingency tables between the presence of strokes (St) that occurred over the Sapienza site (within $10 \mathrm{~km}$ radius in $1 \mathrm{~min}$ ) and convective or stratiform $(C / S)$ minutes recorded by 2-DVD (a), and $\mathrm{IWC}_{\mathrm{g}}$ greater than $0 \mathrm{~g} \mathrm{~cm}^{-3}$ as estimated by Polar 55C over the Sapienza site $(G r)(\mathbf{b})$.

\begin{tabular}{|c|c|c|c|c|c|}
\hline $\begin{array}{l}\text { (a) } \\
C / S \mathrm{r}\end{array}$ & $C / S$ minutes recorded by 2 -DVD & 2-DVD & \multicolumn{3}{|c|}{ IWC $_{\mathrm{g}}$ greater than $0 \mathrm{~g} \mathrm{~cm}^{-3}$} \\
\hline & Yes $(\mathrm{St})$ & No $(\mathrm{St})$ & & Yes $(\mathrm{St})$ & No $(\mathrm{St})$ \\
\hline$C$ & 20 & 11 & Yes $(G r)$ & 58 & 12 \\
\hline$S$ & 21 & 134 & No $(G r)$ & 6 & 5 \\
\hline POD & FAR & ETS & POD & FAR & ETS \\
\hline 0.64 & 0.51 & 0.29 & 0.85 & 0.25 & 0.64 \\
\hline
\end{tabular}

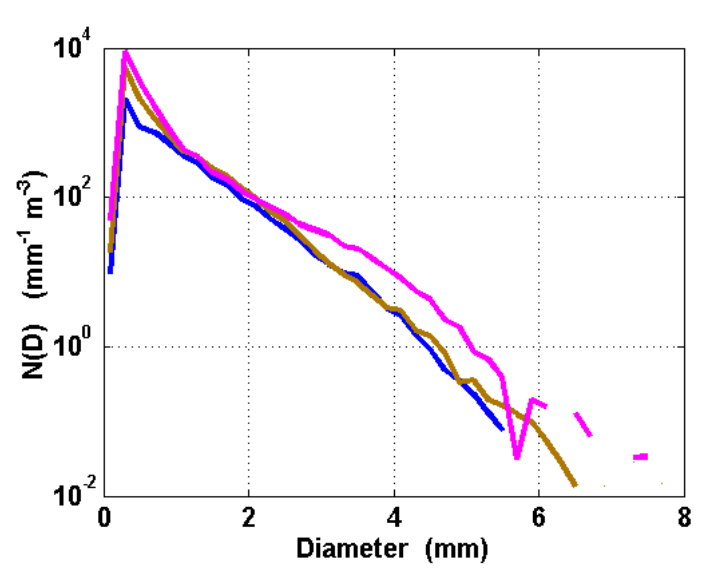

Figure 11. RSD averaged over the convective minutes for 13 September 2012 (blue), 12 October 2012 (brown), and 15 October 2012 (magenta).

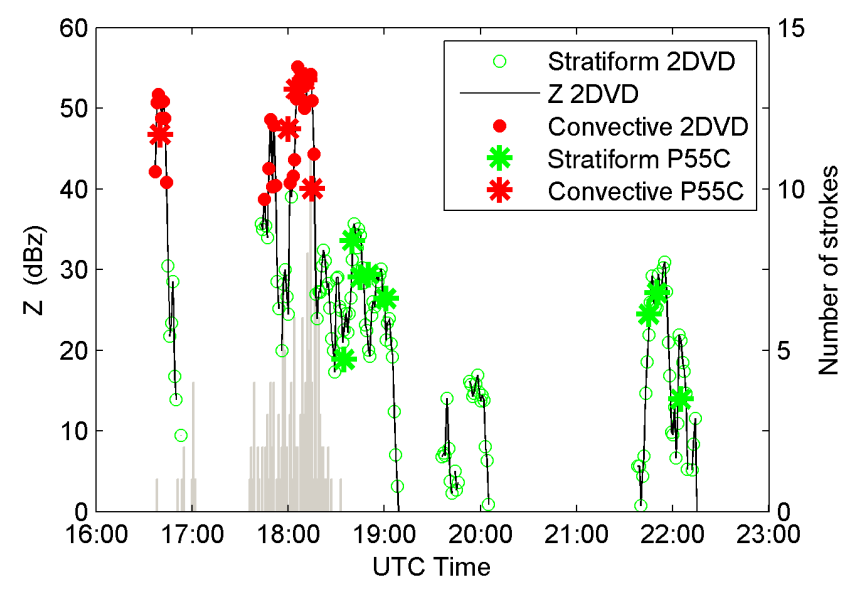

Figure 12. Time series of the reflectivity factors and the number of LINET strokes. Circles represent the reflectivity factor computed from the RSD measured by the 2-DVD, while stars represent the values measured by the Polar 55C radar over the Sapienza site. Green markers indicate stratiform rain, while the red markers indicate convective rain classified with the $C / S$ threshold. Finally, the gray bars are the number of strokes registered in $1 \mathrm{~min}$ in a circular area of $10 \mathrm{~km}$ radius centered at the Sapienza site (2-DVD position). one stroke was detected at that time. Before 17:00 UTC there may not have been sufficient graupel aloft to produce lightning (see also FO13). Between 16:50 and 17:00 UTC, the rain at Sapienza was classified as stratiform, but at that time there were strokes likely associated with the convective cells containing graupel detected by the radar within its coverage area. Furthermore, no graupel was detected by the Polar 55C at the Sapienza site at this time, which agrees with the presence of stratiform rain there. The most intense precipitation was detected between 17:43 and 19:09 UTC, when the most intense lightning activity was registered. Radar reflectivity factor exhibited two peaks during the convective rain, separated by a few minutes classified as stratiform rain around 18:00 UTC (Fig. 12). This trend and the $C / S$ classification agreed with that found from the RHI in Fig. 6a, where two consecutive, intense convective cells spatially separated by a region of uniform hydrometeors (i.e., similar to the bright band present in stratiform precipitation) were detected by the HCA. Lightning activity at the Sapienza site ended by 18:25 UTC, and afterwards, all rain was classified as stratiform.

The relationship between different phases of precipitation (liquid and solid) and the lightning activity over the Sapienza site is found in the contingency tables for all the database (Table 6). Stratiform events calculated using 2-DVD threshold (Table 6a), and the absence of graupel according to the radar $\left(\mathrm{IWC}_{\mathrm{g}}=0\right.$ ) (Table $6 \mathrm{~b}$ ), correspond quite well to the absence of LINET strokes. Statistical scores comparing convective minutes with strokes (Table 6a) and the presence of graupel with strokes (Table 6b) were calculated. Higher probably of detection (POD) and equitable threat score (ETS) and a lower false alarm rate (FAR) are found in Table $6 \mathrm{~b}$ compared to Table 6a, indicating that graupel aloft is better related to lightning activity than surface (liquid) precipitation.

\section{Summary and conclusions}

Convective events that occurred during the HyMeX SOP 1.1 in the CI HyMeX hydrometeorological site, and in particular within the Polar55 $\mathrm{C}$ coverage area, were investigated using observations from three complementary instruments, namely the LINET lightning network, a dual-polarization C- 
band weather radar, and a 2-D video disdrometer. Measurements from the LINET network provided the common framework to interpret different signatures of convection detected by the other instruments and to relate them to lightning activity. The disdrometer, installed $14 \mathrm{~km}$ away from the DP radar, provided estimates of raindrop size distribution at the ground, whereas data from the scanning DP C-band radar were used to analyze important cloud processes related to convection in a wider region. In particular, radar scans at constant azimuths and variable elevations (RHIs) were used to detect the vertical fine structure of convective cells with the support of a fuzzy logic hydrometeor classification system, properly tuned for C-band measurements and for graupel detection. Data from volume scanning, regularly repeated every $5 \mathrm{~min}$, have been used to highlight the relationship between lightning activity (expressed by the number of strokes detected by LINET) and the amount of graupel, whose presence in a radar resolution volume is revealed by the hydrometeor classification algorithm. Using T-matrix simulation results, we formulated a power law relation to obtain graupel IWC from radar reflectivity in order to examine impact of the total mass of graupel on the number of LINET strokes. Among the 11 convective precipitation events that occurred during SOP1.1, three important case studies were analyzed. For these cases, linear relations with different slopes between the total mass of graupel and number of LINET strokes were found. Noticeably, the linear relation found for the case study on 15 October exhibits a high coefficient of determination $\left(R^{2}=0.856\right)$ and a slope in agreement with both TRMM measurements and model results. The variability of the slopes found for different cases can be related to the characteristics of convection, such as the ice mass and the different strength of updraft, although the radar measurement geometry might also play a significant role. The fact that these events developed over the sea and far from the radar (farther than $80 \mathrm{~km}$ ) suggests also a possible influence of observation geometry, while the flux hypothesis suggests that there were differences in the updraft characteristics between the events. Further research, beyond the HyMeX SOP 1.1, will be carried out to investigate these aspects. The relationships found can be considered an important step towards quantifying the microphysical mechanisms that play a role in lightning activity.

To assess the impact of lightning activity on the raindrop size distribution at the ground, we partitioned the 2DVD measured raindrop spectra into stratiform or convective classes and tested the results against the classificationbased polarimetric radar measurements and the number of lightning strokes detected by LINET. Comparison with the classification method based on polarimetric radar measurements showed a fairly good agreement, particularly for the detection of the stratiform regime. A large number of strokes were detected by LINET when rain was classified as convective. Nevertheless, rain was classified as convective also when only a few strokes were detected, associated with a low amount of graupel aloft as estimated from radar mea- surements. High performance in terms of statistical and skill scores was obtained for the presence of graupel in relation to the occurrence of LINET strokes. However, lightning activity was not always found when the precipitation regime was classified as convective. In fact, a certain quantity of graupel aloft is needed to produce strokes although characteristics for convective rain may be observed at the ground.

This study is the first one conducted in Italy with the objective of investigating convection from the point of view of lightning detection networks, raindrop size distributions at the ground, and graupel aloft, as estimated by a dualpolarization weather radar. It has confirmed that a correlation exists between graupel and lightning activity. This aspect is very important to improve the modeling of convection, especially as far as the detection of conditions for triggering lightning and/or convection. However, the differences found among the three main cases considered suggest the need of a more extensive and accurate investigation, considering a larger data set of radar/lightning measurements, trying to separate possible effects of errors related to the geometry of the radar observation from those due to graupel retrieval algorithms.

Acknowledgements. This research has been carried out as a contribution to the SOP 1 of the HyMeX program. The setup of instruments for HyMeX SOP 1.1 in the CI area was possible thanks to a synergy between Italian institutions (CETEMPSUniversity of L'Aquila, ISAC-CNR, DIET-Sapienza University of Rome, University of Ferrara), NASA-GSFC, and the HyMeX coordination. Authors thanks Angelo Viola, Stefania Argentini, Ilaria Pietroni, and Giampietro Casasanta for providing and processing SODAR data. The authors also acknowledge the NASA GPM mission Ground Validation Program under the direction of Matthew Schwaller and Walter A. Petersen, GPM ground validation and science manager, respectively, for providing instruments and expertise, and Arthur Hou, former GPM project scientist (deceased), who promoted the participation of NASA in this campaign.

Edited by: G. Vulpiani

\section{References}

Albrecht, R., Morales, C., and Dias, M.: Electrification of precipitating systems over the Amazon: Physical processes of thunderstorm development, J. Geophys. Res., 116, D08209, doi:10.1029/2010JD014756, 2011.

Aydin, K. and Seliga, T. A.: Radar Polarimetric Backscattering Properties of Conical Graupel. J. Atmos. Sci., 41, 1887-1892, 1984.

Baldini, L. and Gorgucci, E.: Identification of the melting layer through dual-polarization radar measurements at vertical incidence, J. Atmos. Ocean. Tech., 23, 829-839, 2006.

Baldini, L., Gorgucci, E., Chandrasekar, V., and Petersen, W. A.: Implementations of CSU hydrometeor classification scheme for C-band polarimetric radars. Preprints, 32nd Conf. on Radar Meteorology, Albuquerque, NM, Amer. Meteor. Soc., availale at: 
https://ams.confex.com/ams/pdfpapers/95865.pdf (last access: 8 February 2016), 2005.

Baldini, L., Roberto, N., Gorgucci, E., Fritz, J., and Chandrasekar, $\mathrm{V}$.: Analysis of dual polarization images of precipitating clouds collected by the COSMO SkyMed constellation, Atmos Res., 144, 21-37, doi:10.1016/j.atmosres.2013.05.010, 2014.

Barber, P. and Yeh, C.: Scattering of electromagnetic waves by arbitrarily shaped dielectric bodies, Appl. Optics, 14, 2864-2872, 1975.

Beard, K. V. and Chuang, C.: A new model for the equilibrium shapes of raindrops, J. Atmos. Sci., 44, 1509-1524, 1987.

Betz, H.-D., Schmidt, K., Laroche, P., Blanche, P., Oettinger, W. P., Defer, E., Dziewit, Z., and Konarski, J.: LINET - an international lightning detection network in Europe, Atmos. Res., 91, 564573, 2009.

Blyth, A. M., Christian, H. J., Driscoll, K., Gadian, A. M., and Latham J.: Determination of ice precipitation rates and thunderstorm anvil ice contents from satellite observations of lightning, Atmos. Res., 59-60, 217-229, 2001.

Bringi, V. N. and Chandrasekar, V.: Polarimetric Doppler Weather Radar, Cambridge Univ. Press, Cambridge, UK, 2001.

Bringi, V. N., Rasmussen, R. M., and Vivekanandan, J.: Multiparameter radar measurements in Colorado convective storms. Part I. Graupel melting studies, J. Atmos. Sci., 43, 2545-2563, doi:10.1175/15200469(1986)043\%3C2545:MRMICC\%3E2.0.CO;2, 1986.

Bringi, V. N., Chandrasekar, V., Hubbert, J., Gorgucci, E., Randeu, W. L., and Schoenhuber M.: Raindrop size distribution in different climatic regimes from disdrometer and dual-polarized radar analysis, J. Atmos Sci., 60, 354-365, 2003.

Bringi, V. N., Williams, C. R., Thurai, M., and May, P. T.: Using dual-polarized radar and dual-frequency profiler for DSD characterization: a case study from Darwin, Australia. J. Atmos. Ocean. Tech., 26, 2107-2122, 2009.

Carey L. D. and Rutledge, S. A.: A multiparameter radar case study of the microphysical and kinematic evolution of a lightning producing storm, J. Meteorol. Atmos. Phys., 59, 33-64, 1996.

Carey, L. D. and Rutledge, S. A.: The relationship between precipitation and lightning in tropical island convection: A C-band polarimetric radar study: A C-band polarimetric radar study, Mon. Weather Rev., 128, 2687-2710, 2000.

Carey, L. D. and Rutledge S. A.: Characteristics of cloud-toground lightning in severe and nonsevere storms over the central United States from 1989-1998, J. Geophys. Res., 108, 4483, doi:10.1029/2002JD002951, 2003.

Chandrasekar, V., Fukatsu, H., and Mubarak, K.: Global mapping of attenuation at Ku- and Ka-band, IEEE T. Geosci. Remote, 41, 2166-2176, 2003.

Cummins, K. L., Murphy M. J., and Tuel, J. V.: Lightning detection methods and meteorological applications, Proc. Of the IV International Symposium on Military Meteorology, 25-28 September 2000, Malbork, Poland, 2000.

Deierling, W. and Petersen, W. A.: Total lightning activity as an indicator of updraft characteristics, J. Geophys. Res., 113, D16210, doi:10.1029/2007JD009598, 2008.

Deierling, W., Petersen, W. A., Latham, J., Ellis, S., and Christian, H. J.: The relationship between lightning activity and ice fluxes in thunderstorms, J. Geophys. Res., 113, D15210, doi:10.1029/2007JD009700, 2008.
Dolan, B. and Rutledge, S. A.: A theory-based hydrometeor identification algorithm for X-band polarimetric radars, J. Atmos. Ocean. Tech., 26, 2071-2088, 2009.

Dolan, B., Rutledge, S. A., Lim, S., Chandrasekar, V., and Thurai, M.: A robust C-band hydrometeor identification algorithm and application to a long-term polarimetric radar dataset, J. Appl. Meteorol. Clim., 52, 2162-2186, 2013.

Ducrocq, V., Braud, I., Davolio S., Ferretti R., Flamant C., Jansa A., Kalthoff, N., Richard, E., Taupier-Letage I., Ayral, P.A., Belamari, S., Berne, A., Borga, M., Boudevillain B., Bock O., Boichard, J. L., Bouin, M. N., Bousquet, O., Bouvier, C., Chiggiato, J., Cimini, D., Corsmeier, U., Coppola, L., Cocquerez, P., Defer, E., Delanoe, J., Girolamo, P.D., Doerenbecher, A., Drobinski, P., Dufournet, Y., Fourrie, N., Gourley, J.J., Labatut, L., Lambert, D., Le Coz, J., Marzano F.S., Molinie, G., Montani, A., Nord, G., Nuret, M., Ramage, K., Rison, B., Roussot, O., Said, F., Schwarzenboeck, A., Testor, P., Baelen, J.V., Vincendon, B., Aran, M., and Tamayo, J.: HyMeX-SOP 1, the field campaign dedicated to heavy precipitation and flash flooding in the northwestern Mediterranean, B. Am. Meteorol. Soc., 95, 1083-1100, 2014.

Evaristo, R., Bals-Elsholz, T. M., Williams, E. R., Smalley, D. J., Donovan, M. F., and Fenn A.: Relationship of graupel shape to differential reflectivity: Theory and observations. Proceedings, 93rd Amer. Meteor. Soc. Annual Meeting, Austin, TX, USA, Amer. Meteor. Soc., 1-9, 5-10 January 2013, available at: https://ams.confex.com/ams/93Annual/ webprogram/Paper214462.html (last access: 8 February 2016), 2013.

Federico, S., Avolio, E., Petracca, M., Panegrossi, G., Sanò, P., Casella, D., and Dietrich, S.: Simulating lightning into the RAMS model: implementation and preliminary results, Nat. Hazards Earth Syst. Sci., 14, 2933-2950, doi:10.5194/nhess-142933-2014, 2014.

Ferretti, R., Pichelli, E., Gentile, S., Maiello, I., Cimini, D., Davolio, S., Miglietta, M. M., Panegrossi, G., Baldini, L., Pasi, F., Marzano, F. S., Zinzi, A., Mariani, S., Casaioli, M., Bartolini, G., Loglisci, N., Montani, A., Marsigli, C., Manzato, A., Pucillo, A., Ferrario, M. E., Colaiuda, V., and Rotunno, R.: Overview of the first HyMeX Special Observation Period over Italy: observations and model results, Hydrol. Earth Syst. Sci., 18, 1953-1977, doi:10.5194/hess-18-1953-2014, 2014.

Formenton, M., Panegrossi, G., Casella, D., Dietrich, S., Mugnai, A., Sanò, P., Di Paola, F., Betz, H.-D., Price, C., and Yair, Y.: Using a cloud electrification model to study relationships between lightning activity and cloud microphysical structure, Nat. Hazards Earth Syst. Sci., 13, 1085-1104, doi:10.5194/nhess-131085-2013, 2013.

Friedrich, K., Kalina, E. A., Masters, F. J., and Lopez, C. R.: DropSize distributions in thunderstorms measured by optical disdrometers during VORTEX2, Mon. Weather Rev., 141, 1182-1203, 2013.

Gatlin, P. N. and Goodman, S. J.: A total lightning trending algorithm to identify severe thunderstorms, J. Atmos. Ocean. Tech., 27, 3-22, 2010.

Goodman, S. J., Buechler, D. E., and Wright, P. D.: Polarization radar and electrical observations of microburst producing storms during COHMEX, AMS 24th Conference on Radar Meteorology, 27-31 March 1989, Tallahassee FL, USA, 1989. 
Heymsfield, A. J.: The characteristics of graupel particles in northeastern Colorado cumulus congestus clouds, J. Atmos. Sci., 35, 284-295, 1978.

Lagouvardos, K., Kotroni, V., Defer, E., and Bousquet, O.: Study of a heavy precipitation event over southern France, in the frame of HYMEX project: Observational analysis and model results using assimilation of lightning, Atmos. Res., 134, 45-55, doi:10.1016/j.atmosres.2013.07.003, 2013.

Lang, S., Tao, W.-K., Simpson, J., and Ferrier, B.: Modeling of convective-stratiform precipitation processes: Sensitivity to partitioning methods, J. Appl. Meteorol., 42, 505-527, 2003.

Lang T. J. and Rutledge S. A.: Relationships between convective storm kinematics, precipitation, and lightning, Mon. Weather Rev., 130, 2492-2506, 2002.

Latham, J., Blyth, A. M., Christian Jr., J. H., Deierling, W., and Gadian A. M.: Determination of precipitation rates and yields from lightning measurements, J. Hydrol., 288, 13-19, 2004.

Latham, J., Petersen, W. A., Deierling, W., and Christian Jr., H. J.: Field identification of a unique globally dominant mechanism of thunderstorm electrification, Q. J. Roy. Meteor. Soc., 133, 14531457, 2007.

Lim, S., Chandrasekar, V., and Bringi, V. N.: Hydrometeor classification system using dual-polarization radar measurements: model improvements and in situ verification, IEEE Trans. Geosci. Remote Sens., 43, 792-801, 2005.

Liu, H. and Chandrasekar, V.: Classification of hydrometeor based on polarimetric radar measurements: Development of fuzzy logic and neuro- fuzzy systems and in situ verification, J. Atmos. Ocean Tech., 17, 140-164, 2000.

López R. E. and Aubagnac J. P.: The lightning activity of a hailstorm as a function of changes in its microphysical characteristics inferred from polarimetric radar observations, J. Geophys. Res., 102, 16799-16813, doi:10.1029/97JD00645, 1997.

Lynn, B., Yair, Y., Price, C., Kelman, G., and Clark, A. J.: Predicting cloud-to-ground and intracloud lightning in Weather Forecast Models, Weather Forecast., 27, 1470-1488, doi:10.1175/WAFD-11-00144.1, 2012.

Machado, L. A. T, Silva Dias, M. A. F., Morales, C. A., Fisch, G. F., Vila, D., Albrecht, R., Goodman, S. J., Calheiros, A. J. P., Biscaro T, Kummerow C., Cohen, J., Fitzjarrald, D., Nascimento, E., Sakamoto, M., Cunningham, C., Chaboureau, J. P., Petersen, W. A., Adams, D., Baldini, L., Angelis, C. F., Sapucci, L. F., Salio P, Barbosa, H. M. J., Landulfo, E., Souza, R.F., Blakeslee, R.J., Bailey, J., Freitas, S., Lima, W. F., and Tokay, A.: The CHUVA Project - how does convection vary across Brazil?, B. Am. Meteorol. Soc., 95, 1365-1380, 2013.

Marzano F. S., Cimini D., and Montopoli M.: Investigating precipitation microphysics using ground-based microwave remote sensors and disdrometer data, Atmos. Res., 97, 583-600, 2010.

Melani, S., Pasi, F., Gozzini, B., and Ortolani, A.: A four year (2007-2010) analysis of longlasting deep convective systems in the Mediterranean basin, 6th European Conference on Severe Storms 2011, Palma de Mallorca, Spain, Atmos. Res., 123, 151166, 2013.

Miglietta, M. M. and Rotunno, R.: Application of theory to observed cases of orographically forced convective rainfall, Mon. Weather Rev., 140, 3039-3053, 2012.
Mosier, R. M., Schumacher, C., Orville, R. E., and Carey, L. D: Radar nowcasting of cloud-to-ground lightning over Houston, Texas, Weather Forecast., 26, 199-212, 2011.

Petersen, W. A. and Jensen, M.: The NASA-GPM and DOEARM Midlatitude Continental Convective Clouds Experiment (MC3E). The Earth Observer, Vol. 24, Issue 1, Earth Observing System Project Science Office, NASA GSFC, Greenbelt, MD, 12-18, available at: http://eospso.nasa.gov/sites/default/ files/eo_pdfs/Jan_Feb_2012_col_508.pdf (last access: 17 February 2016), 2012.

Petersen, W. A. and Rutledge S. A.: On the relationship between cloud-to-ground lightning and convective rainfall, J. Geophys. Res., 103, 14025-14040, 1998.

Petersen, W. A., Christian Jr., H. J., and Rutledge, S. A.: TRMM observations of the global relationship between ice water content and lightning, Geophys. Res. Lett., 32, L14819, doi:10.1029/2005GL023236, 2005.

Petracca, M., Casella, D., Dietrich, S., Panegrossi, G., and Sanò, P.: Multisensor Atmospheric data Mapping System: a Web-based graphic tool for multisensor observations of atmospheric data and NWP model forecasts, Eumetsat Meteorological Satellite Conference, 16-20 September 2013, Vienna, Austria, 2013.

Preston, A. D. and Fuelberg, H. E.: Improving lightning cessation guidance using polarimetric radar data, Weather Forecast., 30, 308-328, 2015.

Pruppacher H. R. and Klett J. D.: Microphysics of clouds and precipitation, D. Reidel Publishing company, 10-73, 1978.

Saunders, C. P. R.: A review of thunderstorm electrification processes, J. Appl. Meteorol., 32, 642-655, 1993.

Schönhuber, M., Lammer, G., Randeu, W. L.: The 2-D-videodistrometer. Precipitation: advances in measurement, estimation and prediction, edited by: Michaelides, S., Springer, 3-32, 2008.

Sebastianelli, S., Russo, F., Napolitano, F., and Baldini, L.: On precipitation measurements collected by a weather radar and a rain gauge network, Nat. Hazards Earth Syst. Sci., 13, 605-623, doi:10.5194/nhess-13-605-2013, 2013.

Straka, J. M., Zrnic, D. S., and Ryzhkov, A. V.: Bulk Hydrometeor Classification and Quantification Using Polarimetric Radar Data: Sythesis of Relations, J. Appl. Meteorol., 39, 1341-1372, 2000.

Tokay, A., Kruger, W., and Krajewski, J.: Comparison of drop size distribution measurements by impact and optical disdrometers, J. Appl. Meteorol., 40, 2083-2097, 2001.

Tokay, A., Petersen, W. A., Gatlin, P., and Wingo, M.: Comparison of raindrop size distribution measurements by collocated disdrometers, J. Atmos. Ocean. Tech., 30, 1672-1690, 2013.

Wang, P. K.: Mathematical description of the shape of conical hydrometeors, J. Atmos. Sci. 39, 2615-2622, 1982.

Weisman, M. L., Davies, C., Wang, W., Manning, K. W., and Klemp, J. B.: Experiences with 0-36-h explicit convective forecasts with the WRF-ARW model, Weather Forecast., 23, 407437, 2008.

Wiens, K. C., Rutledge, S. A., and Tessendorf, S. A.: The 29 June 2000 supercell observed during STEPS. Part II: Lightning and charge structure, J. Atmos. Sci., 62, 4151-4177, 2005.

Woodard, C. J., Carey, L. D., Petersen, W. A., and Roeder, W. P.: Operational utility of dual-polarization variables in lightning initiation forecasting, Electronic J. Operational Meteor., 13, 79$102,2012$. 
Wu, D., Dong, X., Xi, B., Feng, Z., Kennedy, A., Mullendore, G., Gilmore, M., and Tao, W.-K.: Impacts of microphysical scheme on convective and stratiform characteristics in two high precipitation squall line events, J. Geophys. Res.-Atmos., 118, 1111911135, 2013.

Yair, Y., Shalev, S., Erlich, Z., Agrachov, A., Katz, E., Saaroni, H., Price, C., and Ziv, B.: Lightning flash multiplicity in eastern Mediterranean thunderstorms, Nat. Hazards Earth Syst. Sci., 14, 165-173, doi:10.5194/nhess-14-165-2014, 2014.
Zikmunda, J. and Vali, G.: Fall patterns and fall velocities of rimed ice crystals, J. Atmos. Sci., 29, 1334-1347, 1972.

Zinner, T., Forster, C., de Coning, E., and Betz, H.-D.: Validation of the Meteosat storm detection and nowcasting system Cb-TRAM with lightning network data - Europe and South Africa, Atmos. Meas. Tech., 6, 1567-1583, doi:10.5194/amt-6-1567-2013, 2013. 